Review

\title{
CONCEPTUAL MODEL OF THE LONG-TERM SOCIO-ECOLOGICAL RESEARCH PLATFORM OF ENGURE ECOREGION, LATVIA
}

\author{
Viesturs Melecis*\#, Māris Kḷaviṇš ${ }^{\star *}$, Māris Laiviņš̌, Solvita Rūsiṇa*, Gunta Springǵe*, \\ Jānis Vīksne*, Zaiga Krišjāne ${ }^{\star \star}$, and Solvita Strāḳe \\ * Institute of Biology, University of Latvia, Miera iela 3, Salaspils, LV-2169, LATVIA \\ vmelecis@email.lubi.edu.Iv \\ ** Faculty of Geography and Earth Sciences, University of Latvia, Raiṇa bulv 19, Rĩga, LV-1586, LATVIA \\ ${ }^{* * *}$ Latvian Institute of Aquatic Ecology, Daugavgrivas iela 8, Rīga, LV-1007, LATVIA \\ \# Corresponding author
}

Contributed by Viesturs Melecis

The article discusses the results of the national project aimed at elaboration of a conceptual integrated model of the Engure LT(S)ER (Long-Term Socio-Ecological Research) platform of Latvia. The platform represents the drainage basin of costal Lake Engure $\left(644 \mathrm{~km}^{2}\right)$ together with the coastal marine zone of the Gulf of Riga. The core zone of the ecoregion is the Lake Engure Nature Park (LENP), which is a Ramsar site. The conceptual model is a slightly modified version based on the DPSIR (Drivers-Pressures-States-Impacts-Responses) concept. The socioecological system was spatially demarcated and drivers were subdivided in two groups - external and local ones. The Engure ecoregion was subdivided into seven zones or sub-regions mostly demarcated by natural geological and geographical barriers. Each zone has a specific set of drivers and pressures as well as a specific ecosystem structure and elements of biodiversity. Analysis of the governing drivers and pressures was performed separately for each sub-region during three time periods: $19^{\text {th }}$ century - beginning of $20^{\text {th }}$ century, period of Soviet occupation (1940-1991), and period after restoration of independence of Latvia (1991 - up to now). Characteristics of the state of ecosystems and biodiversity are given. Responses of the socioeconomic component of the socio-ecological system are represented mainly by external factors to the ecoregion, including environmental legislation and funding necessary for research and ecological management. Two alternative scenarios of the development of the Engure ecoregion are discussed: (i) depopulation and land abandonment, and (ii) intensification of agriculture, small-scale industry and building construction. In both cases the present state of ecosystems and the structure of species diversity would be subjected to significant change. Sustainable development of the ecoregion can be provided only by implementation of certain environmental management measures accompanied by long-term socio-ecological research and ecological monitoring.

Key words: Long-Term Ecological Research network, DPSIR concept, socio-ecological systems, Ramsar sites, biodiversity changes.

\section{INTRODUCTION}

Disregarding international level decisions and conservation efforts, ecosystem degradation and loss of biodiversity on the planet is continuing (Butchart et al., 2010). The main reason for this is the lack of an integrated approach to the problems of nature conservation and research-based decision making (Haberl et al., 2009). The International Long-Term Ecological Research network (ILTER) (http://www.ilternet.edu) came up with a new initiative of how to reduce the pressure of integrated socio-economic factors on biodiversity. It is necessary to set up a multidisciplinary research programme on the functioning of socio-ecological systems aimed at discovering process indicators for long-term monitoring to assure sustainability of the system (Haberl et al., 2009; Mirtl et al., 2013). In order to link the long-term changes in ecosystems with the socio-economic pressures, each of the ILTER national networks established a Long-Term Socio-Ecological Research (LT(S)ER) platform (Mirtl et al., 2013; Singh et al., 2013). The LTER-Europe network currently covers 21 member countries and 31 LT(S)ER platforms (Mirtl et al., 2013). 
Some of them have worked out conceptual schemes of interactions within socio-ecological systems based on the DPSIR (Drivers-Pressures-States-Impacts-Responses) concept (Haberl et al., 2009).

In 2010, a national co-operative project was started aimed at elaboration of a conceptual model for the Engure LT(S)ER platform in Latvia. The Engure LT(S)ER region represents the catchment of the coastal Lake Engure, a Ramsar site. In the framework of the project, integrated studies were performed on ecological and social components of the platform. Digital maps were prepared on the distribution of geological and geographical factors (Strautnieks and Grīne, 2011; 2013), structure of landscape and landuse (Penēze u.c., 2013), forest inventory (Laiviņš u.c., 2013), dynamics of tree-ring growth (Dauškane and Elferts, 2011; Elferts et al., 2011), population density, distribution of farmsteads a.o. parameters (Penēze et al., 2013; Strautnieks un Grīne, 2013). For the Lake Engure Nature Park, the core area of the Engure LT(S)ER region, maps of distribution of vegetation, plant and bird species were prepared. The data on soil, sediment and water chemistry (Briede et al., 2000; Klaviņ̌s et al., 2011a; 2011b; Klaviņš u.c., 2013), analysis of the main influencing factors of Lake Engure (Springe et al., 2011), plant community structure and species distribution (Auniņš et al., 2000; Gavrilova and Baroniņa, 2000; Laime, 2000; Gavrilova et al., 2011; Laivin̄š u.c., 2013; Rūsiṇa u.c., 2013), available long-term data on population structure of birds (Vīksne, 1997; 2000; 2013; Vīksne et al., 2011), freshwater and marine aquatic communities (Strāḳe, 2000; Kokorīte u.c., 2013; Strāke u.c., 2013) and sea pollution (Seisuma and Kulikova, 2000; Seisuma et al., 2011); lake and coastal marine fish (Aleksejevs un Birzaks, 2013; Strāķe u.c., 2013), insect communities (Karpa, 2000; Melecis et al., 2000; 2013) were collected and analysed in relation to human activity, including fishery, agriculture, and tourism (Rozīte and Vinklere, 2011; Penēze et al., 2013; Strautnieks and Grīne, 2013). Synthesis of these data allowed to come up with a conceptual integrated model of socio-economic biodiversity pressures and drivers for the Engure LT(S)ER platform. The article discusses the conceptual model of the platform.

\section{MODEL SELECTION}

Social-ecological systems have complex structure and combine an extremly large number of elements. Development of the conceptual model of such a multidimensional stohastic system requires certain guidelines that can be elaborated by integration of knowledge provided by natural and social sciences on the basis of systems theory (Holling, 2001; Gunderson and Holling, 2002). According to Glaser et al. (2008), at least five important approaches can be identified among studies of social-ecological systems since the late 1990s:

- The evolutionary ecological orientation, focusing on adaptive renewal cycles in multi-scale, panarchical structures (Berkes et al., 2003);
- Quantitative/formal approaches, which functionally analyse mutually embedded complementary systems and the conditions for the viability of systems and subsystems (Bossel, 2001);

- The "New Frankfurt School", which examines societynature relations and identifies social-ecological patterns and dynamics that satisfy human needs (Becker and Jahn, 2006);

- Complexity theory, focusing on nonlinear dynamic systems and the transfer of system expertise to strategic planning and adaptive management (Ratter, 2001);

- Pattern and archetype approach based on an intermediate scale of abstraction focusing on reappearing building blocks of social-ecological dynamics (Eisenack et al., 2006).

In addition, the DPSIR framework has been widely used since 1995 by the European Environment Agency and by EUROSTAT, for the organisation of environmental indicators and statistics (Thomas, 1995).

The evolutionary ecological orientation (Berkes et al., 2003 ) is based on the study of how humans, across a wide range of cultural settings, have adapted to ecosystem changes in ways that influence the resilience to external shocks of the social-ecological system.

The quantitative/formal approach (Bossel, 2001) represents a systems-based derivation of a comprehensive set of performance indicators, identification of subsystems within the hierarchical structure of the general system, defining structure of these subsystems and finding conditions for viable functional coexistence of subsystems providing sustainability of the general system.

The "New Frankfurt School" (Berghoefer et al., 2010) considers nature as not just an entity that is somewhere out of human society to be either consumed or protected. Instead, it is constituted through a three-way relationship between the individual, society, and the physical world. The school understands nature not as a given, causal, objective entity, but as a sphere whose boundaries are dynamic and socially constructed.

Complexity theory (Berkes et al., 2003) considers socialecological systems as complex nonlinear open systems capable of self organisation. Reorganisation of such a system is possible at certain critical points of instability. Holling's adaptive renewal cycle (Holling, 2001) is an illustration of reorganisation that takes place within the cycles of growth and renewal.

The pattern and archetype approach (Eisenack et al., 2006) aims to identify the features of single-case studies to develop theories of social-ecological system management success factors, based on large samples of case studies. Archetypes are a suitable way of representing generalisable system features by reducing complex interaction to basic 


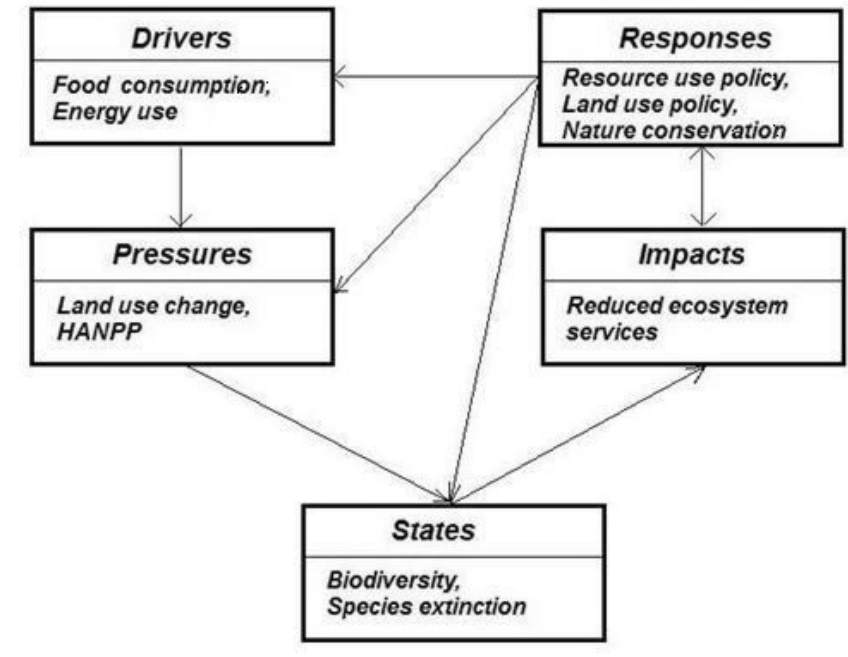

HNPP - Human appropriation of net.primary production

Fig. 1. The DPSIR (Drivers-Pressures-States-Impacts-Responses) framework (after Haberl et al., 2009).

mechanisms. They are used as a pattern approach to this task. The general idea is that each problem class is structured by core interactions, allowing to describe them as typical patterns.

DPSIR evolved as an interdisciplinary tool to provide and communicate knowledge on the state and causal factors regarding environmental issues (Fig. 1). It was developed as a framework for describing interactions between society and the environment (Svarstad et al., 2008). Under the term 'driving forces' is understood socio economic and sociocultural forces driving human activities, which increase or mitigate pressures on the environment. Under the term 'pressures' is understood stresses that human activities place on the environment. 'State' includes variables characterising environmental conditions e.g. pollutant concentration in air or water. 'Impacts' describe effects of environmental degradation e.g. biodiversity loss, decline of population numbers etc. By the term 'responses' is understood the reaction of society to the environmental situation e.g. introduction of cleaner technologies, environmental regulations a.o.

It has been recognised that the strength of the DPSIR framework is that it captures, in a simple manner, the key relationships between factors in society and the environment, and therefore, can be used as a communication tool between researchers from different disciplines and between researchers, on the one hand, and policy makers and stakeholders, on the other (Svarstad et al., 2008). However, during recent years, much criticism has appeared concerning the DPSIR concept (Spangenberg et al., 2002; Gobin et al., 2004; Refsgaard et al., 2006; Maxim et al., 2009). It was concluded that for analytical purposes, the scheme is unsatisfactory. The simple causal relations assumed cannot capture the complexity of interdependencies in the real world. It is a relevant tool for structuring communication between scientists and end-users of environmental information, but it is inappropriate as an analytical tool (Maxim et al., 2009).

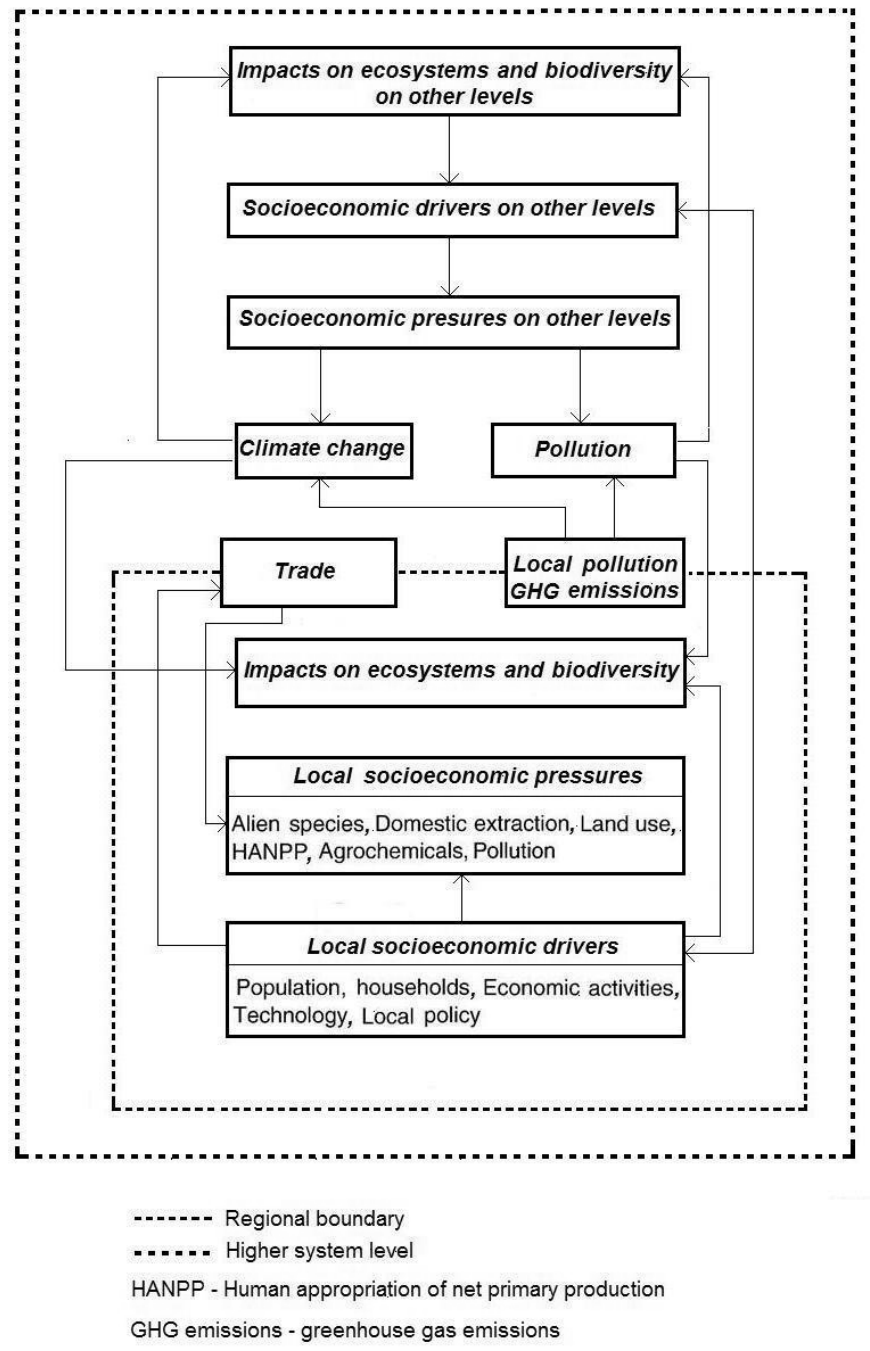

Fig. 2. DPSIR based conceptual model of LT(S)ER platform with specified attributes, describing influence of socioeconomic and environmental factors on the regional biodiversity (after Haberl et al., 2009).

The approaches described above have so far been developed for the most part independently of each other and no comparisons have been made between them concerning their usefulness for modeling of LT(S)ER platforms. Until now, published results (Haberl et al., 2009) are available only on testing of the DPSIR approach in building the conceptual model of LT(S)ER sites. We used guidelines of the DPSIR approach in developing a conceptual model of the Engure LT(S)ER platform (Melecis, 2011; Melecis un Kḷaviňš, 2013). Haberl et al. (2009) changed the DPSIR modelling guidelines by introducing a spatial dimension in defining drivers (Fig. 2).

The system was spatially demarcated and drivers were subdivided in two groups - external and local. They considered an LT(S)ER region as homogenous territory in relation to ecological and socioeconomic factors. In fact this not always occurs. The territory of the Engure LT(S)ER is highly heterogenuous and can be subdivided into several zones or sub-regions with different ecological characteristics (Eberhards and Saltupe, 2000; Melecis et al., 2011). 


\section{SPATIAL STRUCTURE OF THE ENGURE LT(S)ER PLATFORM}

The preliminary version of the conceptual model of the Engure LT(S)ER platform included four sub-regions (Melecis, 2011; Melecis and Klaviņš, 2013). Later, Laiviṇš et al. (2013) proposed more detailed subdivision of the terrestrial part of the region based on geological age of sub-regions (Fig. 3; Table 1):

The Northern Kursa Upland is located on a rise of the sub-Quaternary surface which dips in the direction of the depression of the Gulf of Riga. The Uplands represent the highest relief position of the drainage area (average $53.7 \mathrm{~m}$ above the sea level). This sub-region comprises $48 \%$ of the total area of the Lake Engure drainage basin. Geologically these are the oldest soils which became free from ice cover more than 13 thousand years ago. Glacigenic sediments are formed by loam and sandy loam, soils are poorly drained. Due to articulated relief, drainage conditions of the territory are highly variable. Most of the small rivers of the region begin their flow to Lake Engure from such places (Eberhards and Saltupe, 2000; Strautnieks and Grīne, 2011).

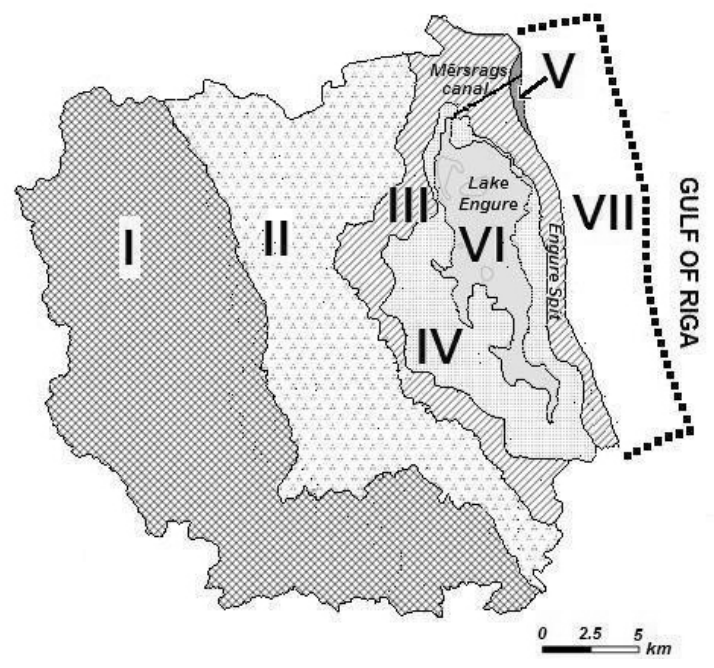

Fig. 3. Structure of sub-regions of the Engure LT(S)ER ecoregion. I Northern Kursa Uplands; II - Baltic Ice Lake plain; III - Littorina Sea plain with Engure Spit; IV - Drained lakebed zone; V - Limnea Sea zone; VI - Lake Engure; VII - Coastal part of the Gulf of Rīga (after Laivin̄š u.c., 2013).

Table 1

GEOLOGICAL AGE AND AREA OF TERRESTRIAL AND AQUATIC SUB-REGIONS OF THE ENGURE LT(S)ER ECOREGION*

\begin{tabular}{lcc}
\hline \multicolumn{1}{c|}{ Sub-region } & Area, $\mathrm{km}^{2}$ & Geological age \\
\hline Nothern Kursa Upland & 292.4 & 13500 \\
Baltic Ice Lake Plain & 181.2 & 11500 \\
Littorina Sea Plain & 125.0 & 7500 \\
Limnea Sea zone & 2.7 & 2800 \\
Drained lakebed zone & 70.7 & 170 \\
Lake Engure & 45 & 4000 \\
Coastal part of the Gulf of Rīga & 110.4 & unknown
\end{tabular}

* After Laivin̄š u.c., 2013)
The sloping plain of the Baltic Ice Lake covers $27 \%$ of the drainage area and falls towards the east and south-east. It represents a lowland covered by marine sediments, dominated by sand, gravel, and organogenic material formed 13500 years ago. The Baltic Ice Lake longitudinally is crossed by sandy inland dunes, which were formed after the regression of the Baltic Ice Lake and can be considered as secondary barriers to natural surface drainage on the surface of the Baltic Ice Lake Plain. For this reason, large areas of wet soils are located in front of the dune belts (Eberhards and Saltupe, 2000; Strautnieks and Grīne, 2011).

The Littorina Sea plain $\left(125 \mathrm{~km}^{2}\right)$ includes lands surrounding Lake Engure. The parent rock was formed about 11500 years ago and is composed of marine sediments, sand, aleirite, and organogenic deposits. The relief of the territory is quite heterogeneous; there are several dune belts on the Engure Spit along the coast of the Gulf of Riga and also on the western part of Lake Engure. However, the average height of the territory above the sea level is only $5.1 \mathrm{~m}$ (Eberhards and Saltupe, 2000; Strautnieks and Grīne, 2011).

The drained lakebed zone $\left(70.7 \mathrm{~km}^{2}\right)$ was formed only 170 years ago after the digging of Merrsrags Canal in 1842, which connected Lake Engure with the sea. The drained lakebed of Lake Engure covers about 13\% of the total area of the drainage basin (Eberhards and Saltupe, 2000).

The Limnea Sea zone is a comparatively small teritory (2.7 $\mathrm{km}^{2}$ ) on the NE part of the Engure LT(S)ER region. The parent material was formed about 2800 years ago by sand and coarser material containing pebble and boulders (Laivin,š u.c., 2013).

Lake Engure belongs to coastal lakes formed as a remnant of Littorina sea about 4000 years ago. Lake Engure is the largest relict water body along the coast, and has remains from the time of the Littorina Sea in the course of marine regression. The Engure Spit occurred initially as a large underwater bar, and later as a spit above water level with beach and parallel dune ridges, separating a bay of several kilometers width from the open sea (Eberhards and Saltupe, 2000).

The geological structure, in particular Quaternary deposits and relief, form the background of the development of soils and landscapes. Soil development shows a pattern of decreasing age from west to east. The soils on the Northern Kursa Upland are older than those on the Baltic Ice Lake and the soils of the later are older than soils in the area of Littorina sea plain. The youngest soils are those in the drained lakebed zone around Lake Engure, which are only 170 years old (Strautnieks and Grīne, 2011).

The underwater part of the coastal area has mostly glacial marine deposits with patchy structure. The sea bottom coverage is very diverse ranging from stone reefs to soft bottoms (Strāķe et al., 2013). The geological age of the deposits is still unknown. 
Geology and relief of zones described above gave rise to a specific ecosystem structure, and hence specific background conditions of development of economy and human settlement.

\section{FLOW-CHART OF CONCEPTUAL MODEL}

The preliminary version of the conceptual model of the Engure LT(S)ER platform (Melecis, 2011; Melecis and Klaviņš, 2013) describes only the spatial aspect of relationships of drivers, pressures and states for an undefined period of time. This model lacks the temporal dimension, which to our opinion is of great importance for this model. The Engure LT(S)ER region has gone through several historical periods with different political systems, each of which is characterised by a different economy, different intensity of man's impact on ecosystems and biodiversity, as well as different public attitudes towards use of natural resources. Without going into fine detail, we pointed out the following three periods:

1. Period from the begining of $19^{\text {th }}$ century to the middle of the $20^{\text {th }}$ century including the time of the first independence of Latvia (1918-1940);

2. Period of Soviet occupation (1940-1991);

3. Period following the restoration of the independence of Latvia (1991 - up to now).

For each of these periods a separate flow-chart was constructed (Figs. 4-6). These periods differed by antropogenic pressure to the landscape, in particular intensity of agriculture and environmental pollution reflected by chemical composition of Lake Engure sediments (Kḷaviňš et al., 2011b).

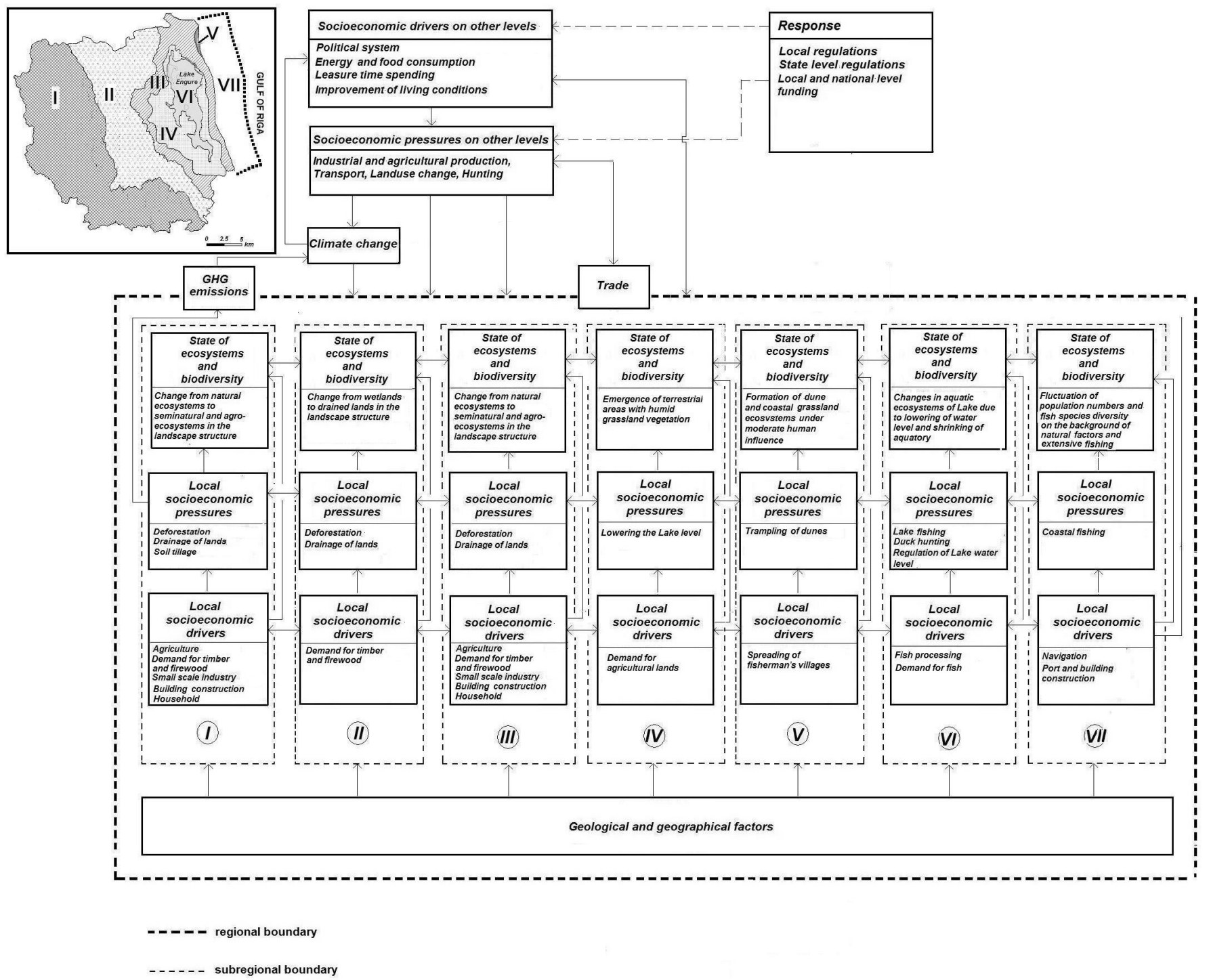

Fig. 4. Flow-chart of the conceptual model of the Engure LT(S)ER platform for the period from the beginning of $19^{\text {th }}$ century to the middle of the $20^{\text {th }}$ century, including the time of the first independence of Latvia (1918-1940). The model is based on the DPSIR (Drivers-Pressures-States-Impacts-Responses) concept. The spatial sub-units (sub-regions) marked by Roman numerals are distinguished by different landscape geological structures and geographical locations. For designations see Fig. 3. 
The $1^{\text {st }}$ period can be characterised by extensive and widespread agriculture (Fig. 4). The territory was subjected to strong deforestation because wood was widely used not only for building construction, but also for heating, iron ore smelting, production of wood-derived tar and charcoal (Barzdeviča, 2013). Increase in population numbers and shortage of lands was the main reason why Lake Engure water level was lowered in 1842 by digging the Mērsrags Canal. Agricultural practices of the estates and private farms were quite environmentally friendly, except maybe at the very end of the period, when modern methods of agriculture started to spread among the most prosperous farmsteads, including wider use of artificial fertilisers. During this period, environmental policy was not well developed. Because no environmental monitoring existed, there is no data for this period on transboundary air pollution brought from industrial regions of Europe. The use of natural resources (forests, game animals, agricultural lands) was governed by the state law and local regulations issued by the nobles. The human society was still living in illusions of inexhaustibility of natural resources, so there was little feedback in the form of 'response'. Only on the very end of the period, during the first Latvian Republic, the first list of protected plant species was published and the first nature reserves were established (Leitis, 2013b).

The $2^{\text {nd }}$ period (Soviet occupation) can be characterised by highly devastating attitude to natural resources (Fig. 5). Private lands were deprived and joined in big collective farms (kolkhozes), and people from single farmsteads were concentrated in village centers of these collective farms. Artificial fertilisers and pesticides were used in large quantities, causing pollution of soils and rivers. Up to the Gorbachev's declaration of Glasnost in 1985, it was officially forbidden to talk about environmental pollution problems in the former Soviet Union. Only in the end of 1980s, a large state-supported environmental monitoring system was implemented under the GIDROMET (the state hydrometeorological committee of the USSR). However, biodiversity conservation was supported by the Soviet ideology long be-

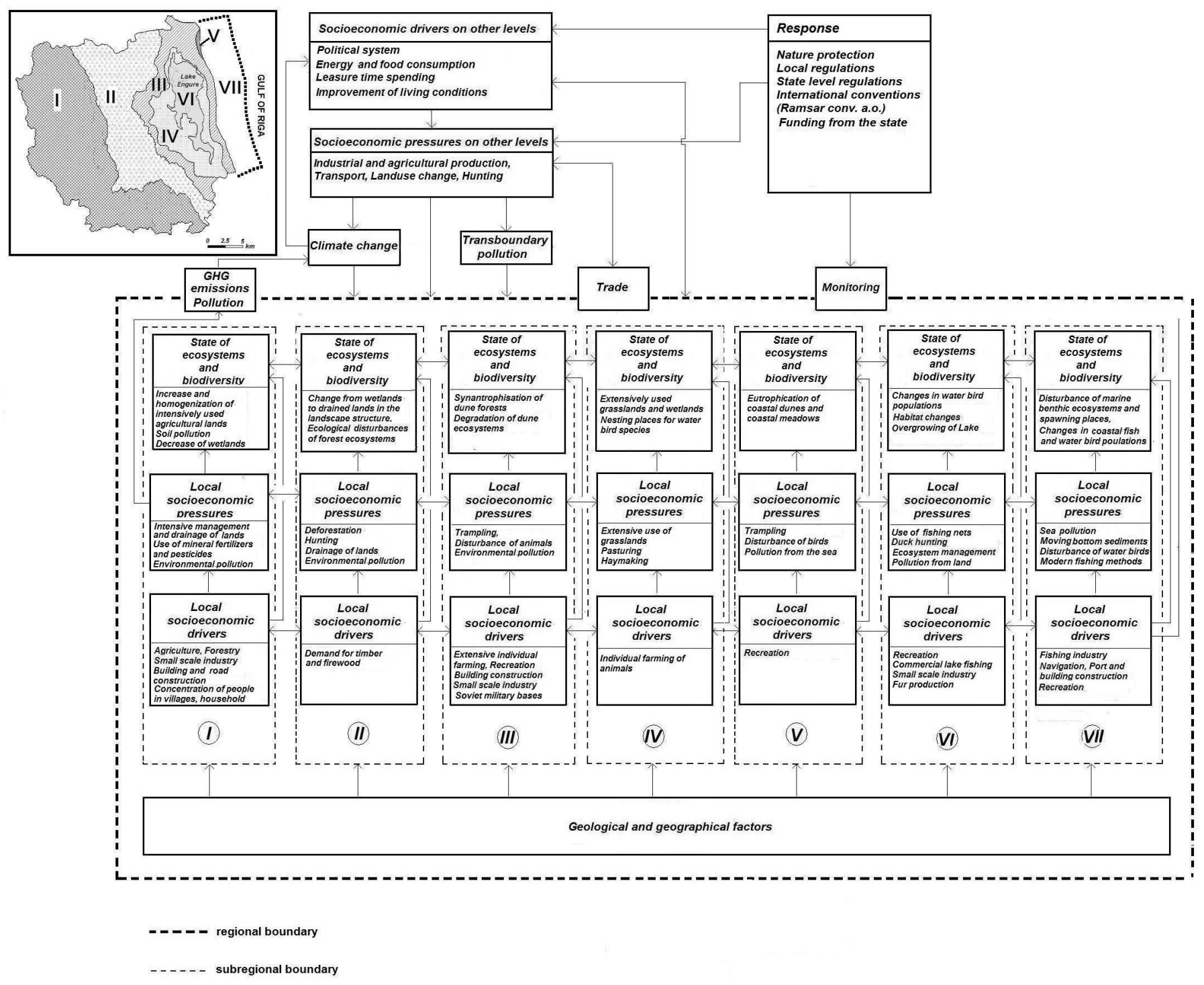

Fig. 5. Flow-chart of the conceptual model of the Engure LT(S)ER platform for the period of Soviet occupation (1940-1991). The model is based on the DPSIR (Drivers-Pressures-States-Impacts-Responses) concept. The spatial sub-units (sub-regions) marked by Roman numerals are distinguished by different landscape geological structures and geographical locations. For designations see Fig. 3. 
fore (Bowers, 1993). During this period many nature protection areas and sanctuaries were established and the first version of the Red Data Book of Latvia was prepared by the Institute of Biology (Leitis, 2013b).

The $3^{\text {rd }}$ period is characterised by a decrease in human pressure to the ecosystems of Latvia (Fig. 6). After the restoration of independence, major restructuring took place in the state policy and economy. Because of significant reduction in industry and removal of Soviet military bases, local environmental pollution decreased (Melecis et al., 1998). Non-economic use of fertilisers and pesticides was stopped in line with land privatisation. However, many new landowners and farmers soon discovered that they could not provide agricultural products to the market by competitive prices. It turned out to be unprofitable to raise cattle even for their own use. Many fields and farms were abandoned and overgrew with secondary forest. Some previously military territories where access for people was limited for many years showed even increase in biodiversity. After the restoration of independence strong emphases was put on the development of a environmental monitoring programme and nature protection. The state monitoring system was developed, which included monitoring of biodiversity. Latvia has signed all the international conventions on the nature protection. After joining the EU, Latvia is committed to comply also with the EU nature conservation directives (Leitis, 2013b).

For each sub-region, local drivers, pressures and most important effects on the ecosystems and biodiversity during the given period of time are shown in the boxes (Figs. 4-6). It should be noted that, like in conceptual models of Haberl et al. 2009 (Fig. 2), no 'impacts' are included in the model as separate flow-chart blocks, because in most of subregions, there was no implemented long-term monitoring of biodiversity changes, except for some ecosystem components of the Lake Engure Nature Park during the last decades. Therefore, there are almost no data from which one can derive the strength of impacts of particular factors on

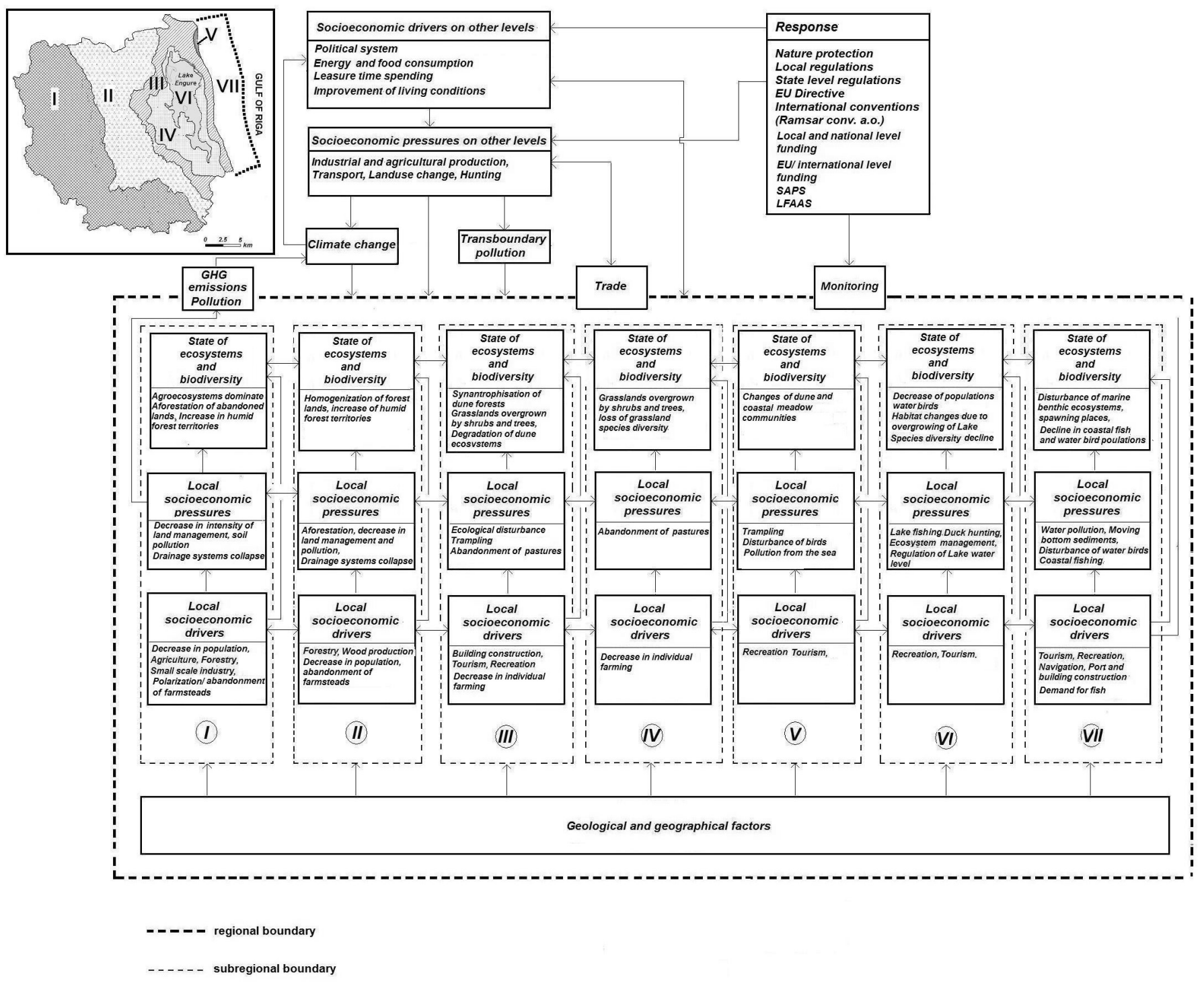

Fig. 6. Flow-chart of the conceptual model of the Engure LT(S)ER platform for the period following the restoration of the independence of Latvia (1991 - up to now). The model is based on the DPSIR (Drivers-Pressures-States-Impacts-Responses) concept. The spatial sub-units (sub-regions) marked by Roman numerals are distinguished by different landscape geological structures and geographical locations. For designations see Fig. 3. 
biodiversity. What is shown is only the result — the present state of the biodiversity component.

The marine coastal zone is of particular significance to the LT(S)ER platform, since from ancient times people have been living in the region, and especially coastal villages have been closely connected with marine fishing, fish processing and trading (Leitis, 2013b; Zēberga un Ërglis, 2013). Human pressure to marine coastal ecosystems stems from multipurpose use of them: navigation, port development, fishing, water pollution, and recreation. The most sensitive and ecologically significant components of marine coastal ecosystems are unique swards of brown algae covering large sea bottom areas along the coast. These are spawning places for economically important fish species.

\section{NORTHERN KURSA UPLANDS}

For the Northern Kursa Uplands, since the early $19^{\text {th }}$ century, the dominating process has been transformation of natural ecosystems into seminatural and agro-ecosystems. The landscape of the North Kursa Uplands is dominated by undulating plain. On the steeper hill slopes, surface runoff predominates, while in the relief depressions due to increased moisture conditions peat bogs have formed. Geology and relief conditions predetermined relatively high agricultural activity of these territories. Already during the $1^{\text {st }}$ period, the territory was subjected to intensive deforestation and amelioration of soils (Fig. 4). During the $2^{\text {nd }}$ period (Fig. 5), even peat soils on relief depressions in many places were ameliorated by artificial drainage (Penēze u.c., 2013). Agricultural development through creation of large fields and application of heavy machinery was not always compatible with sustainable cultivation in hilly conditons, resulting in soil erosion by meltwater. Land became susceptible to erosion by meltwater from snow and rain, with increasing transport of mineral and organic matter and biogenic elements from the soil to watercourses. The short length of the rivers (only some tens of kilometers) and a sufficient natural fall eased transport of sediment and biogenic elements from cultivated areas to Lake Engure and floodplains of the main rivers (Eberhards and Saltupe, 2000).

At present, the landscape structure is dominated by agroecosystems. Forests and shrubs contribute only about $30 \%$ of the area. Forests are highly fragmented. The presence of well drained soils on loamy and sandy loamy bedrock and hilly undulating relief created specific conditions for topography of forest habitats. About half of the forest habitats are eutrophic forest types, the other half are mesotrophic, and only $2 \%$ are oligotrophic. Forest stands are formed by 15 tree species, and the area of coniferous and deciduous forests is similar (Laiviņš u.c., 2013).

Developing agriculture and gardening was responsible for increasing numbers of escaped species from gardens (31 species) and invasive species of plants within the sub-region. However, in general the vegetation of the territory can be regarded as oligo- to mesohemerobic according to classification of vegetation by hemerobity (Laiviņš u.c., 2013).

According to historical data, already during the $17^{\text {th }}$ and $18^{\text {th }}$ centuries, the centres of economical activities were large manors (Strautnieks and Grīne, 2013). During 1918-1939, most of the farmsteads were concentrated around these manors, and during the Soviet occupation these lands were nationalised and joined into big socialistic state farms (kolkhozs). Along with agriculture, local communities were involved also in small-scale enterpraises engaged in processing of agricultural products and wood. The periods of the highest economical activity were in the $19^{\text {th }}$ and $20^{\text {th }}$ centuries, when the territory had the highest population. During the $1^{\text {st }}$ period, dispersion of communities was prevailing, but in the Soviet period most farmsteads were demolished and people moved to newly built collective farm centres with two- to three-storied living houses. Small patches of arable land were rejoined in large uniform agricultural fields and very few balks and field margins remained intact. In the $3^{\text {rd }}$ period, after the restoration of independance of Latvia, this played a crucial role in the socio-economical development of the sub-region. Although many lands were returned back to their previous owners, not all of them were able to start agricultural production in the new competitive conditions. Imported agricultural products outcompeted the local ones, making the local extensive farms nonprofitable. As a result, large territories of agricultural fields and meadows were abandoned and overgrew with bushes. The area of secondary forests was increased by $3 \%$. People who lived in previous collective farm centres became unemployed. Most of them, in particular younger persons, migrated to big cities or emigrated from the country. Strong depopulation of the territory took place. Between 2000 and 2009, the population of municipalities of the sub-region decreased by $7 \%$ (Anonymous, 2012). In this difficult economical situation, the Single Area Payment System (SAPS) and the Less Favoured Area Payment Support Scheme (LFASS) became the key responses for optimisation of the structure of the landscape. About $70 \%$ of agricultural lands of the territory now are receiving SAPS and $40 \%$ are supported by LFASS (Penēze et al., 2013). The new economical situation caused polarisation of private farms. Successful ones even increased their arable lands by leasing territories from land owners not engaged in agricultural production. There appeared a specific term for those land owners not engaged in agricultural production and mostly living far from their land properties in cities 'couch farmers'.

An important factor determining the spatial distribution of agricultural lands was the quality of roads. Due to the low budgets allocated for the road construction and roadworks the quality of roads decreased drastically all over the country. Many smaller peripheral roads leading to strongly underpopulated areas became impassable. Thus, marginalisation processes increased in the landscape (Penēze et al., 2013; Strautnieks and Grīne, 2013). 
Therefore, the main driver for the formation of landscape ecosystem structure of this sub-region still is food production by agriculture, and to a less extent, wood production. The sub-region has no nature-protected areas and is dominated by seminatural ecosystems and agroecosystems.

\section{BALTIC ICE LAKE PLANE}

The zone of the Baltic Ice Lake plain is much less affected by agriculture, because soils are infertile and most of the area suffers from excess moisture. For humans, the only alternative to agriculture there is forestry (Penēze et al., 2013; Strautnieks and Grīne, 2013). More than $90 \%$ of the sandy plain of the Baltic Ice Lake is covered by mesotrophic or oligotrophic pine forests, with isolated farms located only along river valleys. During the $1^{\text {st }}$ to $2^{\text {nd }}$ periods (100-200 years), and particularly in 1850-1990, the wet forests and bogs were specifically targeted for large-scale forest drainage, and meandering rivers with their large flooded meadows for regulation. About $38 \%$ of forests have been drained by a dense network of diches crossing the area (Eberhards and Saltupe, 2000; Laiviņš u.c., 2013).

Due to the low intensity of agriculture, the flora of the region includes very few escaped species from gardens (16 species), which are mosly distributed along roadsides and small river banks. The flora of the region belongs to the mesohemerobic class (Laiviņš u.c., 2013). The territory has a very low population density - less than 7 ind. $/ \mathrm{km}^{2}$, and since the end of $20^{\text {th }}$ century, the population of the area has beenl decreasing. Even previously existing small areas of agricultural lands now are abandoned and afforestation of the region has increased by $14 \%$ since the $20^{\text {th }}$ century. Agricultural areas applying for SAPS or LFASS comprise less than $1 \%$. People are mostly concentrated in villages, which are located on the cross roads with largest towns of the Kurzeme region. Few people are employed in agriculture, the others in small-scale wood industry and fishing (Strautnieks and Grīne, 2011). The landscapes of the sub-region are dominated by seminatural and natural ecosystems, and there are no protected nature reserves.

\section{LITTORINA SEA PLAIN WITH ENGURE SPIT}

The Littorina Sea plain is highly heterogeneous. The flat, sandy depositional belt of the Littorina Sea plain has large areas used for agriculture, interdispersed with patches of forest. The eastern part is the Engure Spit, which represents a unique nature area where, due to lowering of the Lake, natural biotic successions can be seen extending from the Lake shore to the present shore of the Gulf of Riga. It includes reedbeds and 130-160 year-old dune habitats, which form the axis of the spit. There is a successional gradient towards the sea by increasingly recent lower series of parallel dunes ending with a coastal dune having a narrow, mostly overgrown beach and a shallow, gently sloping nearshore zone (Eberhards and Saltupe, 2000; Laiviņš u.c., 2013).
The main anthropogenic factors affecting ecosystems and biodiversity within this zone are land use change, building construction and recreation (Penēze et al., 2013). It should be noted that this zone is particularly rich in ecologically valuable grasslands, used by local people for hay making and pasturing for centuries. At present, small scale farming is not profitable, grasslands are abandoned and have overgrown with shrubs (Rūsin, et al., 2013).

The soils of the Littorina Sea plain developed on nutrient-poor parent material, and there are very few arable lands except pastures and meadows for hay making. The western part of the plain suffers from a high ground water level and poor drainage conditions, because it is covered by a dense set of ditches and most of the small river flows have been regulated. The history of the development of agriculture is rich in projects concerning drainage of agricultural and forest lands. About $25 \%$ of the forests were drained during the $1^{\text {st }}$ and $2^{\text {nd }}$ period. One of the largest projects was the construction of a large polder in the northeast part of the ecoregion, built for transfer of the excess of water from the agricultural lands to Lake Engure (Strautnieks and Grīne, 2011).

The area of the Engure Spit is well drained. Relief and parent material largerly determine the structure of forests of the Littorina Sea plain. On the lowlands of the western part, there are mostly deciduous and mixed forests, while the dunes of the Engure Spit are covered exclusively by oligotrophic pine forests. Human settlements are concentrated mostly on the eastern coastal part of the Engure Spit. Unlike other the areas, this has been subjected to much stronger human pressure. During the $1^{\text {st }}$ and $2^{\text {nd }}$ period the coastal area has been developing as a row of fisherman's villages. There were no agricultural fields, except small gardens around houses. At present on the western part of Lake, economic activities are decreasing with population size, and on the coastal part of the sea building construction is increasing, despite of the fact that fishing and fish processing gradually declined since the early century due to the new EU fishing regulations. Active building of summer houses and small hotels is now taking place in the coastal area (Strautnieks and Grīne, 2011), and therefore the forest areas have decreased by $3 \%$ (Laiviňš u.c., 2013). Unlike many other countrysides of Latvia where the population is decreasing, in the area of the Engure Spit, it increased by $3 \%$ between 1990 and 2010 (Anonīms, 2011a).

Most of the area now belongs to the Lake Engure Nature Park. If strong regulations were not exerted on building construction, it would increase in the coastal area. Due to infertile soils, diversity of forest ecosystems in the area is very low, only eight tree species were recorded. In contrast, gardening activities have resulted in high numbers of escaped species from gardens - 49. However, the vegetation can be classified as mesohemerobic (Laiviņš u.c., 2013).

The LENP is one of the best investigated territories of Latvia regarding species diversity in different groups of organisms. The species lists include 44 mammal species: 5 in- 
sectivores, 5 bats, 2 hares, 14 rodents, 4 ungulates, and 14 carnivores. Among them, brown bear Ursus arctos and wolverine Gulo gulo have been recorded only once (Vītols, 1981). Carnivores include two alien species - raccoon dog Nyctereutes procyonoides and American mink Mustela vison, which have become the most numerous mammalian predators in the LENP and are a serious limiting factor for breeding waterbird populations. Eight mammal species recorded in LENP are included in the Red Data Book of Latvia. Several species which are rare in most European countries, are very common as beaver Castor fiber, and common otter Lutra lutra, wolf Canis lupus and lynx Lynx lynx. Shooting of American mink, raccoon dog and beaver is allowed without bag limits; shooting of wolf and lynx is limited according to population size (Anonīms, 2011c).

Varied moisture conditions ranging from dry sand dunes to a variety of wetlands provide favourable living conditions for both amphibians and the reptiles. There are 14 species of amphibians and reptiles. Four species (Pelobates fuscus, Bufo calamita, Coronella austriaca, and Lacerta agilis) are included in the Red Data Book of Latvia (Andrušaitis, 2003).

LENP is the only location for several rare protected plant species, such as Clubmosses Lycopodium dubium, Little Grapefern Botrychium simplex, Sweet Grass Puccinellia capillaris, and Fly Orchid Ophrys insectifera (Anonymous 2010).

\section{THE DRAINED LAKEBED ZONE}

The geologically youngest area is the drained lakebed zone, which formed after lowering of the Lake's water level in 1842 to release lands for pastures and meadows for hay making. During the $1^{\text {st }}$ period, these lands were used quite actively by local farmers for hay making and pasturing. During the Soviet ocupation period, intensity of use of these lands gradually decreased, partly due to establishment of a nature protection regime on the part of the territory along the lake. Since the begining of 1990s, the territory was practically abandoned and gradually overgrew with shrubs and secondary forest (Vìksne, 1997). In our days, they are hopelessly doomed to overgrow by reeds and shrubs unless large herbivores are introduced (Laiviņš u.c., 2013).

Soil formation took place on marine sediments, sand, aleirite, and organogenic material; therefore, soils there are infertile and suffer from excess moisture and inundation. Vegetation is dominated by short-term unstable communities. The drained parts are covered by mesotrophic forests formed mainly by Scots pine Pinus sylvestris; only seven tree species occur. The scarcity of human settlements and agricultural lands cause low numbers of adventive species and escaped species from gardens (5 and 21, accordingly). However, in general the vegetation of this area can be regarded as mesohemerobic (Laiviňš u.c., 2013). Less than $1 \%$ of agricultural lands receive SAPS or LFASS (Strautnieks and Grīne, 2013).
A large part of the territory belongs to the LENP. Overgrowing of meadows by shrubs and reeds has negative impact on nesting of several protected bird species. Administration of the Nature Park in cooperation with researchers of the Institute of Biology is actively working on effective nature management measures to improve the situation (Vīksne, 1997; Šiliņ̌ and Mednis, 2013). The effects of reed burning was investigated on nesting success of water birds. Since 2004, large herbivores were introduced along the Lake (Šilinšs and Mednis, 2013). The lakebed zone includes many rare habitats (mainly marshlands and forests) of European importance. Among them are large areas of Western taiga (9010), Alluvial forests with Black alder Alnus glutinosa and Weeping Golden Ash Fraxinus excelsior (91E0), residual alluvial forests (91E0), and deciduous swamp woods (9080) (Anonīms, 2011a).

\section{LIMNEA SEA ZONE}

The Limnea sea zone is a unique part, despite its small area, because of ecologically valuable coastal grasslands, which are subjected to direct impact of the sea (Laiviňš u.c., 2013). The dune and meadow habitats contain many protected species of plants. There are several habitats of European importance: perennial vegetation of stony banks (1220), boreal Baltic sandy beaches with perennial vegetation (1640), foredunes (2120), and embrionic dunes (2110). Besides habitats of European importance, there are also habitats significant for Latvia, such as pioneer communities with Grey Hair Grass Corynephorus canescens and dry forests and forest edges with Bloody Cranesbill Geranium sanguineum, Small Pasque Flower Pulsatilla pratensis, and Mountain Parsley Peucedanum oreoselinum (Anonīms, 2011c). Besides those species, the territory also is rich in adventive species and escaped species from gardens (15 and 20 accordingly) and could be atributed to the mesohemerobic vegetation class. This part of the coastal area is still not subjected to building construction, but is affected by recreation and tourism (Laiviņš u.c., 2013).

\section{LAKE ENGURE}

Lake Engure, a Ramsar site, is the core zone of the Engure LT(S)ER region. Lake Engure with its adjacent costal wetlands was given the status of the Ramsar site in 1995 due to its rich bird fauna - 186 nesting species. Many species of birds use the area as a resting place during migration. The state is now responsible for this nature reserve, and all of the regulations concerning nature protection and management measures of habitats are focused on water birds. In 1998, the Lake Engure Nature Park was founded. Special regulations issued by the park administration encompass tourism, recreation, hunting, lake fishing, and other human activities. Based on long-term data, the Lake Engure Nature Park management plan (Anonīms, 2010) was developed and accepted by the Advisory Council of the Nature Park, which included scientific researchers and representatives of regional municipalities. Since 2004, the terri- 
tory is on the NATURA 2000 list (Leitis, 2013a). Regular ornithological monitoring of this area has been performed by the Institute of Biology since 1958. Since 1995, longterm research was started on Lake Engure aquatic ecosystems, the surrounding wetlands and terrestrial ecosystems (Melecis et al., 2005).

The Lake's water chemical composition is determined by geological factors of its formation as well as inflow water chemical composition brought by small rivers of the drainage basin (Klavinšs et al., 2013). The main feature of the chemical composition of the water is high concentration of calcium, which plays essential role in the formation of Lake's biotic communities. Charophytes are the key component of this community responsible for buffering of concentrations of phosphorus brough from the drainage areas by the rivers. Disappearing of Charophyte communities in some places of the Lake and substitution of them by vascular plants should be regarded as warning signal for the degradation of Lake's clear-water state. Until now, Charophytes successfully competed with phytoplankton algae in binding of biogenic substances, mainly phosphorus, brought by the river inflows to the Lake. Concentration of algae remains low and cannot increase to cause „blooming” of the Lake, and the water turbidity remains high (Kokorite et al., 2013).

Man has substantialy changed the ecological conditions of the Lake by lowering its water level already during the 1st period when the Mersrags Canal was dug in 1842. The area of Lake was decreased by half and mean depth by $1.5 \mathrm{~m}$. Today, the average depth is only $0.4 \mathrm{~m}$ and the maximal depth is only $2.1 \mathrm{~m}$ (Vìksne, 1997). During winters with thick ice cover, fish lack oxygen. Man's impact on the Lake's ecosystem by lowering its water level should be regarded as the main pressure responsible for decreasing of species diversity of fish communities during the last centuries (Aleksejevs un Birzaks, 2013). Now, there are only 16 fish species, while still in the 1930s there were at least 4-5 species more, including such common fish as eel Anguilla anguilla, catfish Silurus glanis, pike-perch Stizostedion lucioperca, and carp bream Abramis brama. Connection with the sea through the canal does not substantially affect the fish species communities, mostly being casual as for example migration of salmon Salmo salar, whitefish Coregonus lavaretus and flounder Platichthys flesus in the northern part of the Lake. However, smaller aquatic organisms of benthos have formed specific oligo- and mesohaline species communities in the location where the Lake and sea waters mixing occurs, thereby increasing species diversity of Lake's benthos community (Springe et al., 2011; Kokorite u.c., 2013). In 1966, the goldfish Carassius auratus auratus was introduced to the Lake. Considering its relatively higher resistance to low oxygen levels it may become invasive in the future (Aleksejevs un Birzaks, 2013).

Lake fish communities are under permanent pressure by fishing. The largest amount of fish are obtained by nets. The local fishermen have to buy licenses either for fishing for comercial purpose or for home consumption. Analysis of the data from commercial catches of the previous periods and recent control catches performed each year did not show any decline in most important fish species (Aleksejevs un Birzaks, 2013) suggesting that the laws and restrictions put on the consumption of Lake's fish resources provide sustainable use of these resources.

Long-term research on changes in populations of birds, especially ducks and Black-headed Gull Larus ridibundus, have been carried out (Vìksne, 1997; 2013). These studies showed several, largely human induced factors having direct or indirect effects on bird population numbers and species community structure (Vìksne, 2013) (Fig. 7).

Climate warming as an external factor seems to be responsible for some changes in the species composition of nesting birds observed during the last 50 years (Viksne, 2000). Nine bird species of southern origin (Greylag Goose Anser anser, Gadwall Anas strepera, Collared Dove Streptopelia decaocta, Middle Spotted Woodpecker Dendrocopos medius, Bearded Tit Panurus biarmicus, Savi's Warbler Locustella luscinioides, Great Egret Egretta alba, Ferruginous Duck Aythya nyroca and Red-crested Pochard Netta rufina) have started nesting, while five northern species (Red-breasted Merganser Mergus serrator, Hen Harrier Circus cyaneus, Dunlin Calidris alpine, Ruff Philomachus pugnax and Wood Sandpiper Tringa glareola) have ceased nesting in the region. Cormorant Phalacrocorax carbo (newcomer in Latvian breeding bird fauna) deserves special attention because of its sudden expansion. Among specially protected species at the European level, Cormorant has undergone an almost explosive invasion in many European

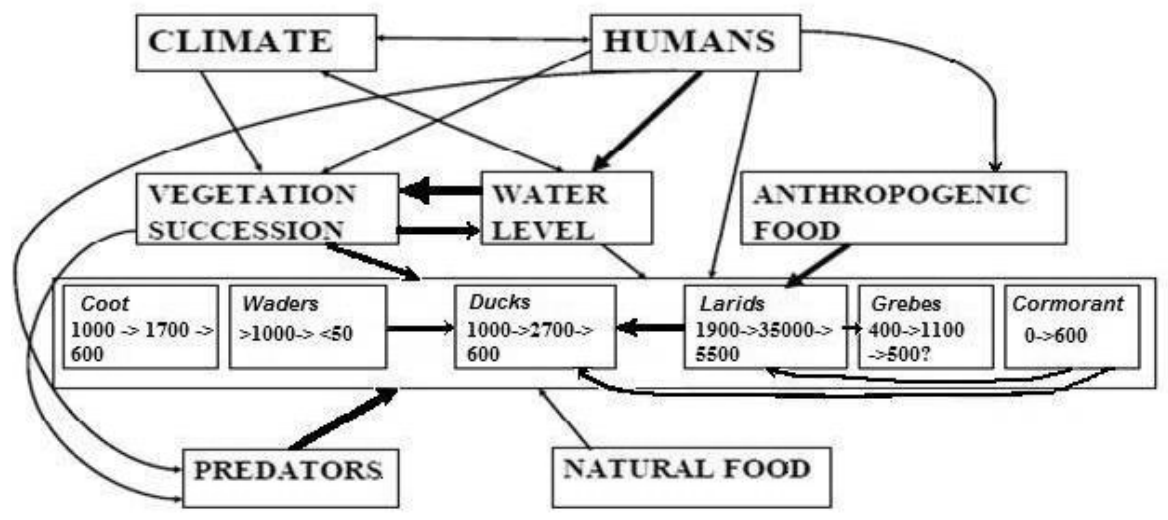

Fig. 7. Relationships between various factors and waterbirds in Lake Engure during 1948-2013. Numbers in boxes describe trends in bird population changes from the begining (first figure) to the end of the period (last figure). For some species also population sizes for the middle of the period in the 1980s are shown (after Viksne et al., 2011). 
countries (including Latvia) during the last decades. The species is highly competitive and nests in big colonies, which have unfavourable effects on the surrounding environment and other bird species, and the species consumes relatively high numbers of fish (Vīksne, 2013).

Lowering of water level changed the Lake's ecosystem, providing favourable conditions for development of emergent vegetation, which in certain stages is an ideal waterbird breeding habitat. Recent observations showed that due to increased precipitation during winter, floods from the drainage basin cause high water levels for longer periods in spring (Kḷaviňš et al., 2011; Kḷaviņš u.c., 2013). Expanding of emergents hinder outflow of water to the sea, and many duck and wader nesting sites remain flooded during the whole breeding season, and thus dabbling duck feeding areas have decreased (Vīksne, 2013).

Successional changes of vegetation are a very powerful factor explaining long-term changes in bird numbers and species composition. As follows from Fig. 7, for Coot, ducks, larids and grebes the highest number of breeding pairs was observed just in the middle of our observation period in the 1970s and 1980s, when there was optimal structure of emergent vegetation. Merging of separate small stands into huge reed dominated massives can explain decline of breeding populations of these waterbirds. Wader populations declined dramatically from the very beginning of observations, due to gradual overgrowing of meadows with reeds and shrubs.

Availability of anthropogenic food (fish in harbors and canneries, mink food in farms) for Black-headed Gull in the surroundings of the lake allowed increase of its population from 170-230 breeding pairs in 1949 to 34000 pairs in 1986. Socialistic mismanagement in fisheries and mink farming was ceased in early 1990s, and Black-headed Gull numbers gradually declined to 4200 pairs in 2002. As several duck species and grebes prefer nesting in Black-headed Gull colonies due to better protection of nests at least from avian predators, decline of Black-headed Gull seems to be one of important reasons of decline in duck populations. This example illustrates how seemingly insignificant human actions (e.g., to cover or not to cover fish boxes with lids in a harbour) up to $70 \mathrm{~km}$ from the Lake can influence bird populations and the whole ecosystem (Vìksne et al., 2011).

Besides successional changes of vegetation and anthropogenic food dependence in Black-headed Gull, also growing predation, mostly by two alien predators - American mink and raccoon dog played notable role in the decline of gull and duck populations. The most harmful for waterbirds is American mink, as it kills incubating females. Moreover, surplus killing was observed quite often. After predation by American mink, Black-headed Gulls attempt to change colony sites to scarce cattail stands, which are unsuitable for duck nesting (Vīksne, 1997; 2013; Vīksne et al., 2011).

Two other human activities can influence bird populations. Fishing in the lake has been mentioned to have negative im- pact on the grebe population. Change of fishing-tackle in the early 1990s from fish baskets to nets increased probability of drowning of grebes, as it is a real threat for less numerous species. Hunting traditionally has been mentioned as a reason of decline in bird numbers. We had the possibility to monitor nesting bird populations in two periods with different hunting intensity: 1958-1990 with very high hunting pressure, intensive predation control, and statistically significant growth of breeding populations and nesting success, versus 1992-2013 with low and declining hunting intensity, insufficient predation control, and statistically significant decline of nesting success and breeding populations. Consequently, even intensive hunting, if habitat management measures (including predation control) secure high nesting success, does not cause duck population decline (Blums et al., 1993; Viksne, 1997; Vìksne et al., 2011). However, it should be mentioned that shooting of some raptor species in the first half of the $20^{\text {th }}$ century resulted in decline and/or disappearance of them (Vīksne, 2013).

\section{COASTAL ZONE OF THE GULF OF RĪGA}

The coastal zone of the Engure LT(S)ER region is a part of the Protected Area „Western Coast of the Gulf of Riga” which was established to protect underwater habitats reefs of EU significance as well as several bird species having concentrations responding to internationally important bird area criteria (two species of Divers Gavia spp., Velvet Scoter Melanitta fusca, Long-tailed Duck Clangula hyemalis and Little Gull Larus minutus). The average depth of the protected area is $20 \mathrm{~m}$, reaching 40 meters in deepest places. About $59 \%$ of the aquatory has $20-40 \mathrm{~m}$ depth, $23 \%$ has $10-20 \mathrm{~m}$ depth and $18 \%$ is a shallow zone $0-10 \mathrm{~m}$ deep (Anonīms, 2009). Geology of the coastal zone largerly determines the structure of marine benthic habitats. This is a highly patchy environment, and each sediment type has a specific species community of marine organisms. There are three types of reefs with depth less than 20 m: (i) moderately exposed hard bottoms with Fucus vesiculosus, (ii) moderately exposed hard bottoms with bivalves and Balanus improvisus and (iii) moderately exposed hard bottoms with no particular species dominance. Soft bottom areas has four types of habitats: (i) moderately exposed soft bottoms with higher plants excluding Zostera marina, (ii) moderately exposed bottoms with charophytes, (iii) moderately exposed soft bottoms with bivalves, and (iv) moderately exposed soft bottoms with no particular species dominance. Underwater reefs and kelp formations are rich in invertebrate species. These places are of great importance for spawning of Baltic hering Clupea harengus, and are feeding sites for other fish species. The kelp formations might be endangered by water pollution and bottom trailing (Anonīms, 2009; Strāḳe u.c., 2013).

Direct inflow of nutients and pollution through the small rivers and Mērsrags Canal from Lake Engure is insignificant. There are still several enterprises on the sea coast discharging poorly treated wastewater in the sea, but in general 
the aquatory cannot be atributed to highly eutrophic and polluted waters (Strākse et al., 2013).

The coastal fishing has strong regulations and restrictions concerning types of fishing equipment, fishing depth and periods. Commercial fishing is regulated by numbers and size of fishing equipmnet. For personal consumtion people need to buy a licence. Commercial fishing catches generally contain 15-20 various fish species, but only 6-8 are of comercial significance (Baltic herring Clupea harengus, perch Perca fluviatilis, vimba Vimba vimba, s napper Abramis brama, flounder Platichthys flesus, garfish Belone belone, whitefish Coregonus lavaretus, eelpout Zorces viviparus). The dominant species are herring (300-600 t per year) and flounder (30-60 t per year) (Strāķe u.c., 2013).

\section{REGIONAL DEVELOPMENT PLANS OF ADMINIS- TRATIVE TERRITORIES}

Land use planning typically follows administrative boundaries, not ecological or natural ones, frequently causing sgnificant problems in ecological management and nature conservation (Forman, 1995; Landres et al., 1998). In 2011, the territory of Latvia was subdivided in 110 municipalities. In order to provide implementation of principles of sustainable development, all the larger administrative units of Latvia were required to develop regional development plans. The administrative structure of the Engure LT(S)ER platform is quite complex (Fig. 8), as the borders of administrative territories do not coincide with watershed boundaries. Even the Lake Engure Nature Park includes parts of four municipalities (Engure, Mērsrags, Talsi, and Tukums). In 2004, according to the Integrated River Basin Management in Europe (EU Water Framework Directive 2000/60/EC from 23.10.2000), the territory of Latvia was subdivided in four zones representing the drainage basins of the largest rivers. The Lake Engure drainage basin is formally included

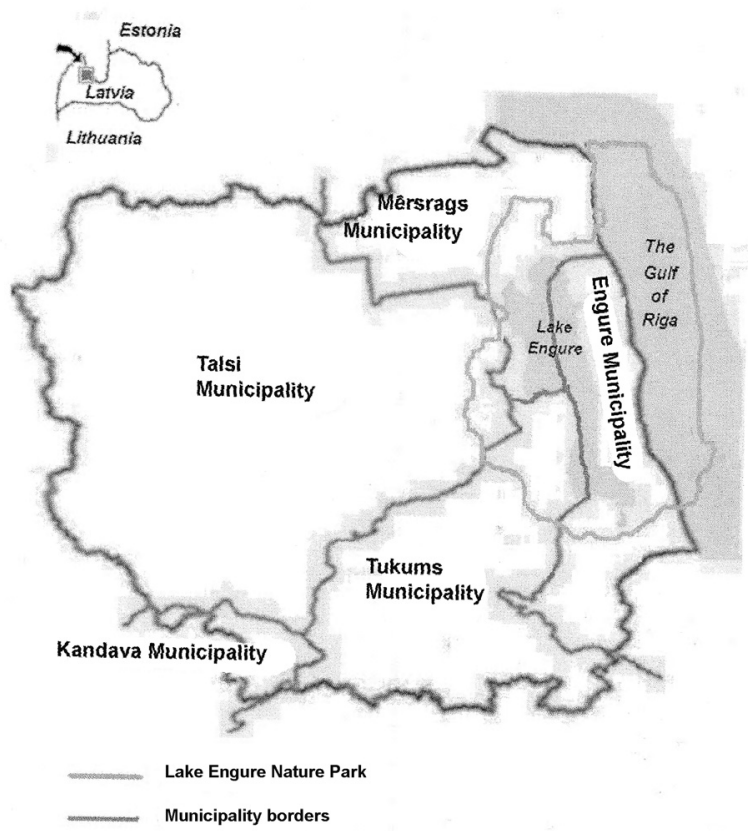

Fig. 8. Administrative structure of the Engure LT(S)ER territory. in the large drainage basin of River Venta, the largest river of the western part of Latvia, but Lake Engure has an independent drainage basin connected directly with the sea via the Mērsrags Canal and has no connection with tributaries of the Venta River.

Each municipality with its part of territory included in the Lake Engure drainage basin has developed regional development plans (Anonīms, 2011a; 2011b; 2011c; 2012). The Lake Engure Nature Park has a nature conservation plan (Anonīms, 2010) and a Nature Management Plans exists also for the Marine Protected Area ,Western Coast of the Gulf of Rìga" (Anonīms, 2009). A development plan of the Engure LT(S)ER platform is still lacking. There are stilll questions of whether it should be worked out by integration and critical assessment of the separate development plans of included administrative units (Leitis, 2013b) or if certain correction should be made to the plans of separate administrative units. Objectives of each individual administrative territory should contain also certain common strategical aspects providing sustainable development of the platform as a whole. For example, planning of development of agriculture in Talsi and Tukums municipalities should be made considering regulation of the flows of biogenic substances to Lake Engure.

It should be noted that the content of regional development plans of separate municipalities is quite similar in relation to the objectives concerning sustainability and nature protection. All the development plans provide:

- Local water management to provide good quality of drinking water and prevent groundwater, streams and marine pollution;

- Improvement of the organisation of waste management, the introduction of waste separation by households;

- Planning of tourism and recreational infrastructure (parking lots, blue flag beaches and tourist trails);

- Strict adherence to the state regulations concerning Environmental Impact Assessment prior to the development of port infrastructure and other building construction projects;

- Sustainability of river valleys and natural dune forests preventing them from building and trampling;

- Provide good agricultural practice to prevent surface and ground water pollution;

- Introduce sustainable forestry, preventing clear cutting of large forest areas and preserving forest belts along rivers.

Only the development plan of the Mērsrags Municipality contains plans for major transformation of the natural environment (Anonīms, 2011c):

- Reconstraction of the port by deepening of its aquatory; 
- Coastal protective construction works, including dune strengthening by planting willows and dune grasses;

- Building wind farms in the sea.

In spite of the comments that strong adherence to state regulations concerning Environmental Impact Assessment prior to the development of these projects will be provided (Anonīms, 2011c), many questions, however, remain about effects of these activities on the biodiversity of the coastal area and the sea. In other cases, development plans of local administrative territories included in the LENP provided specific demands on the nature conservation regime of this territory. The main concerns of the nature protection plan of the LENP are (Anonīms, 2010):

- Regulation of Lake's water level by removal of emergent vegetation and cleaning the water passways to the Mērsrags Canal;

- Mowing of reeds, cutting of shrubs along the coast of Lake and on the largest islands to provide suitable nesting places for water birds;

- Suppression of populations of predatory species such as racoon dogs and American mink by intensification of trapping and hunting;

- Prevent tree cutting in dune forests and damage of dune ecosystems;

- Supporting pasturing of cattle by local people.

The most important task in providing sustainable development of the Engure LT(S)ER platform is the development and improvement of an integrated socio-ecological monitoring programme as feedback for assessment of human influence, and environmental management practices on the background of climate changes. Only implementation of such feedback can provide scientifically based 'response' actions to the ecological changes of the territory.

\section{EXTERNAL INFLUENCES}

External influences are of great significance to the regional ecosystems and biodiversity. There are three main groups of such external factors (Figs. 4-6):

- socioeconomic factors

- climate change

- transboundary pollution

- responses of human society in the form of legislation and funding sources

The main external socioeconomic drivers are energy and food consumption, improvement of living conditions and leasure time spending. These drivers exert a number of pressures, such as increasing industrial and agricultural production, intensification of transport, and land use change.
These pressures are responsible for environmental pollution. As the effects of air pollution from local sources of the ecoregion are insignificant (Melece et al., 2011), the main pollution loads may be of global origin. One of important components brought by the air and precipitation are nitrogen compounds. Some changes in plant and fly community structure observed in our studies (Melecis et al., 2013; 2014; Rūsina et al., 2014) could be regarded as indirect indications for long-term accumulation of nitrogen in soils of oligotrophic habitats.

Hunting as an external pressure can have great effect on migrating bird species populations. Many species which are not hunted in the ecoregion are subjected to illegal hunting in Southern European countries, as well as in Africa on the routes of their migration (Nader, 2013).

The flows of biogenic substance brought by river discharge to the Lake are relatively independent of land use changes outside the Lake Engure drainage basin. The same can not be said in relation to animal populations, which are not strongly attached to the drainage area, and might be affected by landscape fragmentation in adjacent territories. Also, the coastal marine habitats are much more dependent from pollution coming from other parts of the Gulf of Riga, and not from local sources of water pollution due to effective mixing of waters.

Climate change is among the most important factors affecting biodiversity of the region (Vìksne, 2000; 2013; Melecis et al., 2013; 2014). As climate change is resposible also for river discharge intensity and seasonal pattern in the catchment area (Kurpniece et al., 2013) it can affect nesting success of specific water bird species. Ecosystem management can mitigate but not prevent the consequences of this factor. For example, reconstruction of the Mērsrags Canal by increasing its output capacity in response to intensifying of spring floods could improve nesting success of water birds. However, we cannot prevent direct or indirect influences of rising temperatures important for some species. Therefore, in any case we should be prepared for shifts in species composition due to climate warming. Coastal dune and grassland ecosystems can be subjected to impact from the sea by intensification of storms. In case of prevailing SW and W winds and storms, the coast, however, will remain in dynamic equilibrium, beaches will become wider, but the zone of shallow waters will be subjected to minor changes (Anonīms, 2009).

The core area of the Engure LT(S)ER is the Ramsar site, which includes Lake Engure and its coastal areas mostly humid grasslands, marshes, forests, and eastern rows of dunes of the Engure Spit. Uniquely rich bird fauna (186 nesting species) of the area has attracted attention of ornithologists since the middle of the last century. To protect these nature values, already in 1957 a nature protection regime was established in the area (Vìksne, 1997). To strengthen the status of the nature reserve and stress its international significance in 1994, Lake Engure was given the status of Important Bird Areas of Europe, but in 1995 it was assigned 
a Ramsar site status. The LENP was established in 1998 and includes also the seashore of the Gulf of Rìga from Mērsrags to Engure with part of the Protected Area „Western Coast of the Gulf of Rìga”. Since 2004, the Nature Park is on the list of Natura 2000 network (Vīksne, 2013). On each step of formation of this protected territory, legislative acts and regulations were developed for the area (regulations on duck hunting, lake fishing, boating a.o.). An important step towards habitat management was introduction of regular ecological monitoring and long-term research. The longest time series of monitoring (more than 50 years) are on several water bird species. Long-term research of the Lake and terrestrial ecosystems was started in 1995 (Melecis et al., 2005). Long-term data were used to perform system-dynamic modelling of ecological processes of Lake Engure, in particular regarding the dependence of water bird population dynamics on environmental and anthropogenic factors (Zariņš, 2013; Zariņš et al., 2014). Ecological studies clearly showed the need for certain management measures (mowing grasslands and reeds, manipulation of sloughs to increase suitable nesting places) to maintain species diversity of birds. The necessary management actions are given in the nature conservation plan and individual regulations on use and protection (Anonīms, 2010).

The main problem lies in funding of necessary activities, including scientific research, monitoring, and ecological management. During the period of economic crisis, monitoring programmes were interrupted and funding for scientific research was significantly reduced. Untill now, the burden of environmental problems has tended to be solved mostly on money available from EU programmes and international funds (Anonīms, 2011a; 2011b).

The Grassland management project was initiated by the Latvian Fund for Nature in the frame of LIFE-Nature project in 2001. Large herbivores were introduced in 140 ha of the territory. However, this territory should be kept fenced not allowing free migration of wild cows and horses. Increased local concentration of animals led to trampling of soil, overgrazing of vegetation and accumulation of large amounts of excrements (Rūsinga et al., 2013). This caused significant changes in soil animal communities (Melecis et al., 2013; 2014). Therefore, the grazing intensity should be monitored and regulated. Areas for which regular mowing or pasturing is necessary are much larger than those presently managed by the large herbivores. Reeds also should be regularly removed from Lake. Besides money, these management practices require large inputs of manual work, which is difficult to perform unless local people are involved.

\section{TWO SCENARIOUS OF DEVELOPMENT}

The data obtained during the study of the Engure LT(S)ER allow certain predictions concerning its development and biodiversity change. It is reasonable first to describe two extreme alternative scenarious. Between those there exists a set of various possible versions, some of which could represent solutions for sustainable develpoment of the ecoregion.
We consider that there should exist not a single one but several scenarious of sustainability and which one we choose depends, firstly, on the influences of external factors, and second, on the preferences of the local community.

The first scenario considers decline in human population of the ecoregion, and land abandonment. In most parts of the Engure region, as in the whole country, gradual decrease in the human population is expected until 2050 (Anonims, 2012). Slight increase in population was observed only in the territories closer to the sea coast. In some of the coastal villages population size has increased by $9 \%$ since 2000 . This can be explained by strong atraction to buy available land properties, even parts of them from fisherman's families living near the sea coast. As a result of this property change, about one-third of village people in reality are working in Rīga, $71 \mathrm{~km}$ away (Anonīms, 2009). Agricultural activities also are concentrated locally. This results in polarisation and marginalisation of the landscape and abandonment of agricultural lands away from arterial roads and village centers (Penēze et al., 2013; Strautnieks and Grīne, 2013). Declines in agriculture and forestry lead to considerable shifts in the structure of the landscape. Grasslands will gradually overgrow by shrubs and secondary forests. Forests will become a dominant element in the lanscape. Lack of land-reclamation activities will cause silting of the dich network and waterlogging of lands. Areas of old humid forests and marshlands will increase. Hence, the vegetation structure and animal communities will restructure towards forest and marshland communities, while species of open mesotrophic habitats, including many protected ones, will become extinct. Due to afforestation of the Northern Kursa Uplands, the load of silt and biogenic substances will decrease from small rivers to Lake Engure, increasing the life span of the Lake. However, it can hardly stop the aggressive expansion of reeds and emergent vegetation in the Lake, due to supply of biogenic substance accumulated previously (Kḷaviňš et al., 2011a; 2013). Due to decrease of human activities in the coastal zone, the coastal waters and benthic communities of the Gulf of Riga will improve, unless affected by the polluted waters from the other parts of the Gulf of Rìga.

An alternative extreme scenario is an increase of intensive agriculture, forestry, and small-scale industry within the ecoregion. It was demonstrated by our studies that human activities, in particular intensification of agriculture in the drainage basin has been reflected in Lake deposits (Kḷaviňš et al., 2011), as well as in the dynamics of emergent macrophytes (Brižs, 2011). Environmental pollution from the terrestrial part during the periods of intensive agriculture, small-scale industry and household are also reflected in sea sediments (Seisuma and Kulikova, 2000; Seisuma et al., 2011). As predicted by this scenario, area of agricultural lands will significantly increase, forests will be subjected to clear cutting, land drainage will lead to shrinking of moist habitats. Loads of biogenic substances and pollution from agricultural fields will increase the rate of overgrowing of Lake Engure. Following deforestation, much available sedi- 
ment will be produced as a result of land erosion. This will be washed offshore and extensive sedimentary deltas will be formed, which may include wetlands, lagoons, saltmarshes and sand dunes.

The coastal area will be subjected to building of living houses and tourism infrastructure. Coastal grasslands and dune habitats will be subjected to degradation by trampling. The LENP will become surrounded by anthropogenic landscape causing disturbance and pollution of the Lake's ecosystems.

In general, decline in local economy will not benefit ecosystems and biodiversity. The trajectory of ecosystem development in the absence of man would lead to degradation of the Ramsar site, overgrowing of the Lake by reeds, total loss of grasslands and valuable orchid habitats, and decline in most species of water birds. A certain level of human activities should be present in the area to provide acceptable landscape structure and functioning of local ecosystems at the present state. The optimal level of economic activities could provide income from the local small enterprises and farms to cover the necessary ecosystem management, maintaining grassland biodiversity, regulation of predatory mammals (American mink, racoon dog, and red fox), combat of invasive species of plants (e.g. Heracleum sosnowskyi). However, the flow of tourists is too small to provide considerable inputs to the local economy (Leitis, 2011; Rozite and Vinklere, 2011). It seems that funding of nature protection, research and monitoring programmes should come from external sources. It is important for the ecoregion to be involved in various international environmental projects. To integrate socio-economic activities and promote sustainable long-term development of the region a model for environmental management should be strengthened, considering that the landscape structure does not coincide with administrative divisions. Collaboration in nature protection from the Council of Lake Engure Nature Park joining representatives from four administrative regions, parts of which belong to the LENP, should be extended to much wider area of the Engure LT(S)ER platform (Leitis, 2013b).

\section{ACKOWLEDGEMENTS}

The study was performed by the Latvia LTER in the framework of the following national research projects financed by Latvian Council of Science: 02.0009 (1995-2001); 15.1-008 (2002-2005); 6.0033 (2006-2010), and 10.0004 (2010-2013). The authors expressed the utmost gratitude to all participants of the project that contributed to its development.

\section{REFERENCES}

Aleksejevs, $\bar{E}$., Birzaks, J. (2013). Engures ezera ihtiofauna [The fish of Lake Engure]. Grām.: Kḷaviņš, M., Melecis, V. (red.). Cilvēks un daba: Engures ekoregions (107.-120. lpp.). Rīga: LU Akadēmiskais apgāds (in Latvian).

Andrušatis, G. (ed.) (2003). Red Data Book of Latvia. Rare and threatened species of plants and animals. Vol. 5. Fishes, Amphibians, Reptiles. Rīga: Institute of Biology, University of Latvia. 144 pp.
Anonīms (2009). Aizsargājamās jūras teritorijas „,Rīgas līča rietumu piekraste” dabas aizsardzības plāns [Nature Management Plan for Marine Protected Area „Western Coast of the Gulf of Rīga”]. Rìga: Baltijas Vides forums. 102 lpp. (in Latvian).

Anonīms (2010). Dabas parks „Engures ezers”. Dabas aizsardzības plāns. Engures novads, Rojas novads, Tukuma novads, Talsu novads. Plāns izstrādāts laika posmam no 2011. gada līdz 2025. gadam [Nature Park „Lake Engure”, Nature conservation plan. Engure Municipality, Roja Municipality, Tukums Municipality, Talsi Municipality. Plan developed for the period 2011-2025]. SIA „Eiroprojekts”. 104 pp. (in Latvian).

Anonīms (2011a). Engures novada integrètās attīstības programma 2012.-2018. gadam [Integrated development programme of Engure Municipality in 2012-2018] SIA „NK Konsultāciju birojs”. 59 pp. (in Latvian).

Anonīms (2011b). Tukuma novada integrētās attīstības programma 2011.-2017. gadam [Development Programme of Tukums Municipality for 2011-2017]. Tukuma novada dome, 182 pp. (in Latvian).

Anonīms (2011c). Mērsraga novada teritorijas plānojuma 2011.-2023. gadam stratēéiskais ietekmes uz vidi novērtējums [Strategic Environmental Assessment of Mērsrags Municipality Spatial Plan for 2011-2023] Mērsrags, 117 pp. (in Latvian).

Anonīms (2012). Talsu novada attīstības programma 2014.-2020. gadam. 1. daḷa. Pašreizèjās situācijas analīze [Development Programme of Talsi Municipality for 2014-2020. Part 1. Analysis of the Present Situation]. Talsi, 153 pp. (in Latvian).

Auniņš, A., Zviedre, E., Brūmelis, G. (2000). Preliminary results of remote sensing based vegetation mapping of Lake Engures (Engure), Latvia. Proc. Latvian Acad. Sci. Sect. B, 54 (5/6), 170-176.

Barzdeviča, M. (2013). Engures muižas teritorija, iedzīvotāji un saimniecība (17. gs. beigas - 19. gs. sākums) [Territory, population and economy of Engure estate (end of the $17^{\text {th }}$ century - beginning of the $18^{\text {th }}$ century)]. Grām.: Kḷavin̄š, M., Melecis, V. (red.). Cilvēks un daba: Engures ekoreǵions (362.-375. lpp.). Rīga: LU Akadēmiskais apgāds (in Latvian).

Becker, E., Jahn, T. (2006). Soziale Ökologie: Grundzüge einer Wissenschaft von den gesellschaft - lichen Naturverhältnissen. Frankfurt am Main: Campus Verlag. $521 \mathrm{~S}$.

Berghoefer, U., Rozzi, R., Jax, K. (2010) Many eyes on: Diverse perspectives in the Cape Horn Biosphere Reserve and their relevance for conservation. Ecol. Soc., 15 (1), 18. http://www.ecologyandsociety.org/ vol15/iss1/ art18/ (accessed 22 December 2011).

Berkes, F., Colding, J., Folke C. (2003). Navigating Social-Ecological Systems: Building Resilience for Complexity and Change. Cambridge, UK: Cambridge University Press. 393 pp.

Blums, P., Bauga, I., Leja, P., Mednis, A. (1993). Breeding population of ducks on Engure lake, Latvia, for 35 years. The Ring, 15 (1-2), 165-169.

Bossel, H. (2001) Assessing viability and sustainability: A systems-based approach for deriving comprehensive indicator sets. Conserv. Ecol., 5 (2), 12. http://www.consecol.org/vol5/iss2/art12/ (accessed 22 December 2011)

Bowers, S. R. (1993). Soviet and Post-Soviet Environmental Problems. J. Soc. Pol. Econ. Studies, 18 (2), 131-158.

Briede, A., Kḷaviňs, M., Rodinov, V. (2000). Chemical composition of Lake Engures (Engure), Latvia. Proc. Latvian Acad. Sci., Section B, 54 (5/6), $160-163$.

Brižs, J. (2011). Dynamic of emergent macrophytes for 50 years in the coastal Lake Engure, Latvia. Proc. Latvian Acad. Sci., Section B, 65 (5/6), $170-177$.

Butchart, S. H. M., Walpole, M., Collen, B., van Strien, A., Scharlemann, J. P. W., Almond, R. E. A., Baillie, J. E. M., Bomhard, B., Brown, C., Bruno, J., Carpenter K. E., Carr, G. M., Chanson J., Chenery, A. M. , Csirke J., Davidson, N. C., Dentener, F., Foster, M., Galli, A., Galloway, J. N., Genovesi, P., Gregory, R. D., Hockings, M., Kapos, V., Lamarque, J.-F., Leverington, F. ,Loh, J., McGeoch, M. A., McRae, L., Minasyan, A., 
Morcillo, M. H., Oldfield. T. E. E., Pauly, D., Quader, S., Revenga, C., Sauer, J. R., Skolnik, B., Spear, D., Stanwell-Smith, D., Stuart, S. N., Collins, S. L., Carpenter, S. R., Swinton, S. M., Symes, A., Tierney, M., Tyrrell, T. D., Vié, J.-C., Watson, R. (2010). Global Biodiversity: Indicators of Recent Declines. Science, 328 (5982), 1164-1168.

Dauškane, I., Elferts D. (2011). Influence of climate on Scots pine growth on dry and wet soils near Lake Engure in Latvia. Estonian Journal of Ecology, 60 (3), 225-235

Eberhards, G., Saltupe, B. (2000). Geological history, relief, and deposits of the Lake Engures (Engure) area along the Baltic Sea. Proc. Latvian Acad. Sci. Sect. B, 54 (5/6), 141-147.

Eisenack, K., Lüdeke, M., Kropp, J. (2006) Construction of archetypes as a formal method to analyze socialecological systems. Proceedings of the Institutional Dimensions of Global Environmental Change Synthesis Conference. Bali, 6-9. December. www2.bren.ucsb.edu/\%7Eidgec/papers/ Klaus_Eisenack.pdf (accessed 22 December 2011).

Elferts, D., Dauškane, I., Ūsele, G., Treimane, A. (2011). Effect of water level and climatic factors on the radial growth of black alder. Proc. Latvian Acad. Sci. Sect. B, 65 (5/6), 164-169.

Forman, R.T.T. (1995). Land Mosaics: The Ecology of Landscapes and Regions. Cambridge: Cambridge University Press. 632 pp.

Gavrilova, G., Baronina, V. (2000). Vascular plant flora of the Lake Engures (Engure) drainage basin, Latvia, and the coastal zone of the Gulf of Riga. Proc. Latvian Acad. Sci. Sect. B, 54 (5/6), 177-179.

Gavrilova, G., Laivinš, M., Priede, A., Medene, A. (2011). Alien flora in the Lake Engure Nature Park. Proc. Latvian Acad. Sci. Sect. B, 65 (5/6), $154-163$.

Glaser, M., Krause, G., Ratter, B., Welp, M. (2008) Human/Nature Interaction in the Anthropocene: Potential of Social-Ecological Systems Analysis. GAIA, 17 (1), 77-80.

Gobin, A., Jones, R., Kirkby, M., Campling, P., Govers, G., Kosmas, C., Gentile, A. R. (2004). Indicators for pan-European assessment and monitoring of soil erosion by water. Environ. Sci. Pol., 7, 25-38.

Gunderson, L. H., Holling, C. S. (eds.) (2002). Panarchy. Understanding Transformations in Human and Natural Systems. Washington, D.C.: Island Press. 507 pp.

Haberl, H., Gaube, V., Díaz-Delgado, R., Krauze, K., Neuner, A., Peterseil, J., Plutzar, Ch., Singh, S. J., Vadineanu, A. (2009). Towards an integrated model of socioeconomic biodiversity drivers, pressures and impacts. A feasibility study based on three European long-term socio-ecological research platforms. Ecol. Econ., 68 (6), 1797-1812.

Holling, C. S. (2001) Understanding the Complexity of Economic, Ecological, and Social Systems. Ecosystems 4, 390-405.

Karpa, A. (2000). Flies (Diptera, Brachycera) of the Lake Engures (Engure) Nature Park, Latvia. Proc. Latvian Acad. Sci. Sect. B, 54 (5/6), 203-212.

Kḷaviņš, M., Kokorīte, I., Rodinovs, V., Avotniece, Z., Spriņg̨e, G., Briede, A. (2011a). Hydrometeorological parameters and aquatic chemistry of Lake Engure: Trends of changes due to human impact and natural variability. Proc. Latvian Acad. Sci. Sect. B, 65 (5/6), 138-145.

Kḷavin̄š, M., Pujāte, A., Kokorīte, I., Kalniņa, L., Rodinovs, V., Ansone, L., Mažeika, J., Jankēvica, M., Bogans, E., Švāgere, A. (2011b). Reconstruction of past anthropogenic impact intensity in Lake Engure using sedimentary record analysis. Latvia. Proc. Latvian Acad. Sci. Sect. B, 65 (5/6), 146-153.

Kḷaviņš, M., Kokorīte, I., Rodinovs, V. (2013). Engures ezera ūdeṇu sastāvs un to ietekmējošie faktori [The waters of Lake Engure and influential factors]. Grām.: Kḷaviňš, M., Melecis, V. (red.). Cilvēkss un daba: Engures ekoreǵions (107.-120. lpp.). Rīga: LU Akadēmiskais apgāds (in Latvian).

Kokorīte, I., Spriṇğe, G., Briede, A., Druvietis, I., Grīnberga, L., Konošonoka, I., Parele, E., Rodinovs, V., Skuja, A., Zviedre, E. (2013). Engures ezera hidroekosistēmas attīstība un to ietekmējošie faktori [The development of Lake Engure's hydroecosystems and their influential fac- tors]. Grām.: Klavinš, M., Melecis, V. (red.). Cilvēks un daba: Engures ekoreǵions (121.-134. lpp.). Rīga: LU Akadēmiskais apgāds (in Latvian).

Kurpniece, L., Latkovska, I., Apsīte, E. (2013). Engures ezera sateces baseina upju noteces ilgtermina izmainas 20. un 21. gadsimtā [Long-term changes in the discharge channels in the Lake Engure river basin in the $20^{\text {th }}$ and $21^{\text {st }}$ centuries]. Grām.: Kḷaviňš, M., Melecis, V. (red.). Cilvēks un daba: Engures ekoreǵions (91.-106. lpp.). Rīga: LU Akadēmiskais apgāds (in Latvian).

Laime, B. (2000). Seashore plant communities of the Lake Engures (Engure) Nature Park, Latvia. Proc. Latvian Acad. Sci. Sect. B, 54 (5/6), 190-196.

Laivin̄š, M., Gavrilova, G̦., Medene, A. (2013). Veǵetācijas struktūra un attīstība Engures ezera sateces baseinā [The structure and development of vegetation in Lake Engure's river basin]. Grām.: Kḷaviņš, M., Melecis, V. (red.). Cilvēks un daba: Engures ekoreǵions (174.-198. 1pp.). Rīga: LU Akadēmiskais apgāds (in Latvian).

Landres, P. B., Knight, R. L., Pickett, S. T. A., Cadenasso, M. L. (1998). Ecological effects of administrative boundaries. In: Knight, R. L., Landress, P. B. (eds.). Stewardship Across Boundaries (pp. 39-64). Covelo, CA: Island Press.

Leitis, E. (2011). Tourism policy and management for conservation of biodiversity in the Lake Engure catchment area. Proc. Latvian Acad. Sci. Sect. B, 65 (5/6), 198-205.

Leitis, Ē. (2013a). Engures ezera sateces baseina ilgtspējīgas attīstības vēsturiskie aspekti — Engures jūrskolas fenomens [The historical aspects of the Lake Engure river basin's long-term development - the Engure Naval School phenomenon]. Grām.: Klavinšs, M., Melecis, V. (red.). Cilvēks un daba: Engures ekoreǵions (322.-361. 1pp.). Rīga: LU Akadēmiskais apgāds (in Latvian).

Leitis, Ē. (2013b). Attīstības plānošanas loma Engures ezera sateces baseina vides aizsardzības un ilgtspējīgas apsaimniekošanas nodrošināšanā [The role of development planning for ensuring the Lake Engure river basin's environmental protection and long-term management]. Grām.: Kḷaviņš, M., Melecis, V. (red.). Cilvēks un daba: Engures ekoreǵions (294.-321. lpp.). Rīga: LU Akadēmiskais apgāds (in Latvian).

Maxim, L. Spangenberg, J. H., O'Connor, M. (2009) An analysis of risks for biodiversity under the DPSIR framework. Ecol. Econ., 69 (1), 12-23.

Melece, I., Karpa, A., Laiviņš, M., Melecis, V. (2011). Environmental quality assessment of the drainage basin of Lake Engure using Scots pine as a bioindicator. Proc. Latvian Acad. Sci. Sect. B, 65 (5/6), 178-185.

Melecis, V., Karpa, A., Kalvinia, L., Timofejeva, I. (1998). Recovery of pine stands as a result of decreasing of background pollution. Proc. Latvian Acad. Sci. Sect. B, 52, 38-42.

Melecis, V., Vīksne, J., Spriṇǵe, G., Briede, A., (2005). Long-term ecological research in Latvia. Acta Zool. Lithuan., 15 (2), 142-145.

Melecis, V. (2011). Project on development of a conceptual integrated model of socioeconomic biodiversity pressures, drivers and impacts for the long-term socioecological research platform of Latvia. Proc. Latvian Acad. Sci. Sect. B, 65 (5/6), 206-212.

Melecis, V., Karpa, A., Spunggis, V. (2000). Assessment of the strategy used for insect population monitoring in the Lake Engures (Engure) Nature Park, Latvia. Proc. Latvian Acad. Sci. Sect. B, 54 (5/6), 197-202.

Melecis, V., Karpa, A., Vilks, K. (2013). Divspārnuu (Diptera, Bracycera) skaita un sugu bagātības izmaiņas Engures dabas parkā uz antropogēno faktoru un klimata pasiltināšanās fona [Changes in abundance and species richness of flies (Diptera, Brachycera) in the Nature Park Lake Engure on the background of anthropogenic factors and climate warming]. Grām.: Kḷaviņš, M., Melecis, V. (red.). Cilvēks un daba: Engures ekoreğions (223.-248. lpp.). Rīga: LU Akadēmiskais apgāds (in Latvian).

Melecis, V., Karpa, A., Vilks, K. (2014). Increase in abundance and species richness of flies (Diptera, Brachycera) in the Lake Engure Nature Park, Latvia: Effects of climate warming? Proc. Latvian Acad. Sci. Sect. B, 68 $(1 / 2), 44-67$. 
Melecis, V., Kḷaviňs, M. (2013). Socioecological Solutions to the Problem of Biodiversity Decline. Grām.: Kḷaviņš, M., Melecis, V. (red.). Cilvēks un daba: Engures ekoregoions (18.-28. lpp.). Rīga: LU Akadēmiskais apgāds (in Latvian).

Melecis, V., Krišjāne, Z., Kḷavinšs, M., Aigars, J., Elferts, D., Vīksne, J. (2011). Preliminary characteristics of ecological and socioeconomic components and their interaction within the long term socioecological research platform of Latvia. Sci. J. Riga Tech. Univ., Ser.: Environ. Climate Technol., 12 (7), 87-93.

Mirtl, M., Orenstein, D., Wildenberg, M., Peterseil, J., Frenzel, M. (2013). Development of LTSER Platforms in LTER-Europe: Challenges and Experiences in Implementing Place-Based Long-Term Sopcio-ecological Research in Selected Regions. In: Singh, J. R., Haberl, H., Chertow, M., Mirtl, M., Schmid, M. (eds.). Long-Term Socio-Ecological Research. Studies in Society-Nature Interactions Across Spatial and Temporal Scales (pp. 409-442). Springer.

Nader, A. N. (2013). Report on the hunting situation in the Lebanon. Committee Against Bird Slaughter (CABS) \& Lebanon Eco Movement. Bonn. http://www.komitee.de/en/actions-and-projects/species-prote ction/hunting-lebanon/lebanon-report-poaching (accessed 22 April 2014).

Penēze, Z., Krūze I., Medene, A. (2013). Ainavas Engures ezera sateces baseinā un tās ietekmējošie faktori [Landscapes in the Lake Engure river basin and their influential factors]. Grām.: Kḷaviňš, M., Melecis, V. (red.). Cilvēks un daba: Engures ekoreğions (61.-90. 1pp.). Rīga: LU Akadēmiskais apgāds (in Latvian).

Ratter, B. M. W. (2001). Natur, Kultur und Komplexität - Adaptives umweltmanagement am Niagara Escarpment in Ontario, Kanada. Berlin: Springer, $315 \mathrm{~S}$.

Refsgaard, J. C., van der Sluijs, J. P., Brown, J., van der Keur, P. (2006). A framework for dealing with uncertainty due to model structure error. Advances Water Res., 29 (11), 1586-1597.

http://dx.doi.org/10.1016/j.advwatres.2005 (accessed 22 December 2011).

Rozìte, M., Vinklere, D. (2011). Tourism and recreation as a driving force for forecasting biodiversity changes: Lake Engure watershed area as an example. Proc. Latvian Acad. Sci., Section B, 65 (5/6), 192-197.

Rūsina, S., Gavrilova, G., Roze, I., Šulcs, V. (2014). Temporal species turnover and plant community changes across different habitats in the Lake Engure Nature Park, Latvia. Proc. Latvian Acad. Sci. Sect. B, 68 (1/2), $68-79$.

Rūsina, S., Priede, A., Toča, L. (2013). Dabiskie zālāji Engures ezera sateces baseinā - izmirstošas ekosistēmas vai neapzināts resurss? [Natural grasslands in the Lake Engure river basin — dying ecosystems or unknown resources?]. Grām.: Kḷavin̄š, M., Melecis, V. (red.). Cilvēks un daba: Engures ekoregions (199.-222. 1pp.). Rīga: LU Akadēmiskais apgāds (in Latvian).

Seisuma, Z., Kulikova, I. (2000). Metals in sediment and water of coastal zone and the Gulf of Riga, the Baltic Sea. Proc. Latvian Acad. Sci. Sect. B, $54(5 / 6), 148-154$.

Seisuma, Z., Kuḷikova, I., Botva, U., Boikova, E. (2011). Long-term investigation of metal concentrations in brown algae Fucus vesiculosus from the Gulf of Rīga, Baltic Sea. Proc. Latvian Acad. Sci. Sect. B, 65 (5/6), 186-191.

Singh, J. R., Haberl, H., Chertow, M., Mirtl, M., Schmid, M. (2013). 1. Introduction. In: Singh, J. R., Haberl, H., Chertow, M., Mirtl, M., Schmid, M. (eds.). Long-Term Socio-Ecological Research. Studies in Society-Nature Interactions Across Spatial and Temporal Scales (pp. 1-28), Springer.

Spangenberg, J. H. (2002) Environmental space and the prism of sustainability: Frameworks for indicators measuring sustainable development. Ecol. Ind., 2, 295-309.

Springe, G., Briede, A., Druvietis, I., Grinberga, L., Konosonoka, I., Parele, E., Rodinovs, V., Skuja, A. (2011). Long-term Development of
Hydroecosystem of the Lake Engure and its Influencing Factors. Sci. J. Riga Techn. Univ. Ser.: Environ. Climate Technol., 13 (7), 100-105.

Strāke, S. (2000). Variations of mezozooplakton species composition, abundance, and biomass in the littoral zone of the Gulf of Riga, Latvia. Proc. Latvian Acad. Sci. Sect. B, 54 (5/6), 155-159.

Strāḳe, S., Ikauniece, A., Alberte, M., Bārda, I., Jurgensone, I., Lavrinovičs, A., Livdāne L., Puriņa, I., Purviņa, S., Rimša, E., Strode, E., Fedoroviča, D., Kurakins, A., Holodkēvičs, S., Balode, M. (2013). Rīgas līča rietumu piekrastes ekosistēma: vides kvalitāte un bioloğiskā daudzveidība [The ecosystem of the west coast of the Gulf of Rìga: Environmental quality and biological diversity]. Grām.: Kḷaviņš, M., Melecis, V. (red.). Cilvēks un daba: Engures ekoreğions (249.-287. 1pp.). Rīga: LU Akadēmiskais apgāds (in Latvian).

Strautnieks, I., Grīne, I. (2011). Lake Engure catchment area as an example of the interaction of natural conditions, settlement pattern and economic activities. Proc. Latvian Acad. Sci. Sect. B, 65 (5/6), 117-126.

Strautnieks, I., Grīne, I. (2013). Engures ezera sateces baseina ǵeoloǵiskā uzbūve un reljefs: to nozīme zemes lietojumveida un apdzīvojuma struktūrā [The geological structure and relief of the Lake Engure river basin, their significance regarding land use and inhabitation structure]. Grām.: Kḷavin̄š, M., Melecis, V. (red.). Cilvēks un daba: Engures ekoreǵions (29.-60. lpp.). Rīga: LU Akadēmiskais apgāds (in Latvian).

Svarstad, H. A., Petersen, L. K., Rothman. D., Siepel, H., Watzold. F. (2008). Discursive biases of the environmental research framework DPSIR. Land Use Pol., 25, 116-125.

Šiliņš, R., Mednis, A. (2013). Dažādu apsaimniekošanas pasākumu ietekme uz Engures ezeru un tā piekrastes ekosistēmām [The influence of various management measures on Lake Engure and its coastal ecosystems]. Grām.: Kḷaviņš, M., Melecis, V. (red.). Cilvēks un daba: Engures ekoreǵions (288.-293. 1pp.). Rīga: LU Akadēmiskais apgāds (in Latvian).

Thomas, R. (1995). A General Strategy for Integrated Environmental Assessment at the European Environment Agency. Bilthoven: RIVM (National Institute of Public Health and Environment), $35 \mathrm{pp}$.

Vīksne, J. (1997). The Bird Lake Engure. Rīga: Jāņa Sēta. 111 pp.

Vìksne, J. (2000). Changes of nesting bird fauna at the Engure Ramsar site, Latvia, during the last 50 years. Proc. Latvian Acad. Sci. Sect. B, 54 (5/6), 213-220.

Vīksne, J. (2013). Engures ezera ūdensputnus ietekmējošie faktori [Factors influencing waterfowl on Lake Engure]. Grām.: Kḷavin̄š, M., Melecis, V. (red.). Cilvēks un daba: Engures ekoreğions (143.-173. lpp.). Rīga: LU Akadēmiskais apgāds (in Latvian).

Vìksne, J., Janaus, M., Mednis, A. (2011). Factors influencing the number of breeding water birds in Lake Engure, Latvia. Proc. Latvian Acad. Sci. Sect. $B, 65$ (5/6), 190-196.

Vìtols, G. (1981). Tinis - Gulo gula (L.) - Engures medību saimniecībā [Wolverine in Engure hunting management area] - Retie augi un dzīvnieki. Apskats. Rīga, LatZTIZPI, 50.-51. 1pp. (in Latvian).

Zariņš, M. (2013). Sistēmdinamikas izmantošanas iespējas Engures ezera vides procesu modelēšanā [Use of system-dynamics for modelling of environmental processesin the Lake Engure ecoregion]. Grām.: Kḷavin̄š, M., Melecis, V. (red.). Cilvēks un daba: Engures ekoreǵions (403.-413. lpp.). Rīga: LU Akadēmiskais apgāds (in Latvian).

Zariņš, M., Blumberga, A., Kḷaviņš, M., Melecis, V. (2014). System dynamic modelling for environmental proceses: A case study of Lake Engure. Proc. Latvian Acad. Sci. Sect. B, 68 (1/2), 20-30.

Zēberga, L., Ērglis, D. (2013). Apdzīvojuma vēsturiskās pārmaiṇas 20. gadsimtā Engures ezera sateces baseinā: Mērsraga piemērs [Historical changes in the $20^{\text {th }}$ century in the inhabitation of the Lake Engure river basin: The example of Mērsrags]. Grām.: Kḷaviņš, M., Melecis, V. (red.). Cilvēks un daba: Engures ekoreǵions (376.-402. 1pp.). Rīga: LU Akadēmiskais apgāds (in Latvian). 


\section{ILGTERMIN̦A SOCIOEKOLOĢISKO PĒTĪJUMU PLATFORMAS KONCEPTUĀLAIS MODELIS ENGURES EKOREG̦IONAM LATVIJĀ}

Rakstā apskatīti nacionālā pētījumu projekta rezultāti, kuru mērkiis — izstrādāt Latvijas LT(S)ER (Ilgtermiṇa socioekoloǵisko pētījumu) platformas - Engures ekoreǵiona integrēto konceptuālo modeli. Engures ekoreǵionu veido piekrastes ezera sateces baseins $\left(644 \mathrm{~km}^{2}\right)$ ar Rīgas līča krasta un jūras piekrastes zonu. Ekoreǵiona centrālo daḷu veido Engures ezera dabas parks (EEDP) - Ramsāres vieta. Konceptuālā modeḷa pamatā ir DPSIR (virzošie spēki-slodzes-stāvokḷi-ietekmes-rīcības) koncepcija. Socioekoloğiskā sistēma tika telpiski strukturēta un virzošie spēki iedalîti divās grupās - ārējos un lokālos. Engures ekoreǵions sadalīts septiṇās zonās vai apakšreǵionos ar izteiktām ǵeoloğiskām un ǵeogrāfiskām robežām. Katrai zonai raksturīgi specifiski virzošie spēki un slodzes kā arī specifiska ekosistēmu struktūra un biodaudzveidības elementi. Analizēta katra apakšreǵiona galvenie virzošie spēki un slodzes trijos laika periodos: 19. gs. - 20 gs. sākums, padomju okupācijas periods (1940.-1991. g.), periods pēc Latvijas neatkarības atgūšanas. Sniegti ekosistēmu stāvokḷa un biodaudzveidības raksturojumi. Socioekonomiskās sistēmas aktīvā komponenta - cilvēka rīcības veido galvenokārt ekoreǵionam ārējie faktori, tai skaitā vides likumdošana un finansu plūsmas zinātniskajiem pētījumiem un ekosistēmu apsaimniekošanai. Apskatīti divi alternatīvi Engures ekoreǵiona attīstības scenāriji: 1) iedzīvotāju skaita samazināšanās un lauksaimniecības zemju aizaugšana; 2) lauksaimniecības, vietējās ražošanas uzṇēmumu un būvniecības intensifikācija. Abos gadījumos ekosistēmu pašreizējais stāvoklis un sugu daudzveidības struktūra tiktu būtiski izmainīti. Reğiona ilgtspējīgu attīstību, saglabājot cilvēkam vēlamo ekosistēmu struktūru, iespējams nodrošināt, vienīgi ieviešot ekosistēmu apsaimniekošanas pasākumus, kas bāzēti uz ilgtermiṇa socioekoloğisko pētījumu un ekoloğiskā monitoringa rezultātiem. 